\title{
Do bank bailouts have an impact on the underwriting business?
}

Carbo-Valverde, Santiago; Cuadros Solas, Pedro; Rodriguez Fernandez, Francisco

\section{Journal of Financial Stability}

\author{
DOI: \\ https://doi.org/10.1016/j.jfs.2020.100756
}

Published: 31/08/2020

Peer reviewed version

Cyswllt i'r cyhoeddiad / Link to publication

Dyfyniad o'r fersiwn a gyhoeddwyd / Citation for published version (APA):

Carbo-Valverde, S., Cuadros Solas, P., \& Rodriguez Fernandez, F. (2020). Do bank bailouts have an impact on the underwriting business? Journal of Financial Stability, 49, [100756]. https://doi.org/10.1016/j.jfs.2020.100756

\footnotetext{
Hawliau Cyffredinol / General rights

Copyright and moral rights for the publications made accessible in the public portal are retained by the authors and/or other copyright owners and it is a condition of accessing publications that users recognise and abide by the legal requirements associated with these rights.

- Users may download and print one copy of any publication from the public portal for the purpose of private study or research.

- You may not further distribute the material or use it for any profit-making activity or commercial gain

- You may freely distribute the URL identifying the publication in the public portal ?
}

Take down policy

If you believe that this document breaches copyright please contact us providing details, and we will remove access to the work immediately and investigate your claim. 


\title{
Do bank bailouts have an impact on the underwriting business?
}

\author{
Santiago Carbó-Valverde \\ (scarbo@cunef.edu) \\ CUNEF $^{a}$, Bangor University ${ }^{b}$ and Funcas ${ }^{c}$ \\ Pedro J. Cuadros-Solas \\ (pedro.cuadros@ cunef.edu) \\ CUNEF $F^{a}$ and Funcas ${ }^{c}$ \\ Francisco Rodríguez-Fernández \\ (franrod@ugr.es) \\ University of Granada ${ }^{d}$ and Funcas ${ }^{c}$
}

${ }^{a}$ CUNEF. C/ Leonardo Prieto Castro, 28040 Madrid, Spain

${ }^{b}$ Bangor University, Hen Goleg, College Road, Bangor, LL57 2DG, United

Kingdom

${ }^{c}$ Funcas, C / Caballero de Gracia, 28, 28013 Madrid, Spain

${ }^{d}$ University of Granada, C/Campus Cartuja s/n, 18011,Granada, Spain

Corresponding author: Pedro J. Cuadros-Solas (pedro.cuadros@cunef.edu)

Acknowledgments: The authors would like to thank the Editor, Iftekhar Hasan and two anonymous referees for their helpful comments. We are also very grateful for the comments provided on this paper from Paolo Mistrulli, John V. Duca, Larry D. Wall, Javier Suárez, David Martínez-Miera, Yu Shan, Jens Hagendorff, Jung-Eun Kim, Marcus Pramor, Rocco Macchiavello, Diego Rodríguez-Palenzuela, Ana I. Fernández, Ana I. Moro, Juan Antonio Lacomba and Antoni Garrido, as well as conference participants at the 2019 FMA Annual Meeting in New Orleans, the 15th International WEAI Conference (IBEFA) in Tokyo (Japan) in 2019, the 27th Finance Forum in Madrid (Spain) in 2019, the 14th International WEAI Conference (IBEFA) in Newcastle (Australia) in 2018, the 92nd Western Economic Association International in San Diego in 2017, and the 5th FINEST Conference in Trani in 2017. Financial support from the FUNCAS Foundation, PGC2018 - 099415 - B - 100 MICINN/FEDER/UE, ECO2017-87581-P and Junta de Andalucía P12.SEJ.2463 (Excellence Groups) is gratefully acknowledged. 


\title{
Do bank bailouts have an impact on the underwriting business?
}

\begin{abstract}
:
We explore the effects of bank bailouts on competition in the underwriting business. We exploit a sample of underwriters active in the European corporate bond markets from 2006-2013 and find that reputable underwriters suffer market share losses (of 12.43\%) after being bailed out. However, the market share of non-reputable underwriters is found to increase after a bail out. An exploration of the firm-bank underwriting matching reveals that the probability of being chosen as underwriter in a given deal decreases for reputable bailed-out banks, while it increases for non-reputable bailed-out banks. These results provide evidence of the effects of bailouts on underwriting competition. The economic impact depends on the ex-ante reputational capital of the bailed-out bank.
\end{abstract}

Keywords: underwriters, bailout, reputation, recapitalization

JEL Classification: G24, G21, H81 


\section{INTRODUCTION}

The 2007-2008 financial crisis led to the implementation of large bank bailout programs across a number of economies. Despite their main purpose of restoring financial stability and bank soundness, these bailouts have had unintended effects on bank competition (Berger \& Roman, 2015; Calderon \& Schaeck, 2016; Koetter \& Noth, 2016). Prior studies have examined these effects by focusing on banks' role as deposit takers and credit providers (Berger \& Roman, 2015; Black \& Hazelwood, 2013; Hakenes \& Schnabel, 2010; Li, 2013). However, together with these traditional banking activities, underwriting has become a substantial revenue-generating activity for many banks. For investment banks, underwriting ${ }^{1}$ has traditionally played a key role. However, unsurprisingly, many commercial banks have entered the underwriting business at a time when other revenue sources have become less noticeable ${ }^{2}$.

Because underwriting requires minimal capital investment, its strategic importance for banks has grown ${ }^{3}$. Furthermore, information asymmetries in financial markets make underwriting a market for external certification, with implications for firms' access to capital markets.

The growth in banks' underwriting arms (Figure I) began around the time of the financial crisis of 2007-2008, when some of these institutions had to be bailed out. These interventions may also have had unintended effects on banks' underwriting businesses. Moreover, these measures may have implications for the real economy, since firms'

\footnotetext{
${ }^{1}$ Currently, the expressions "lead underwriter" and "underwriter" are used indistinctly in the industry and the literature. In this paper, we use the term "underwriter" to refer to the "lead underwriters" of a deal. While other non-lead members could form a syndicate, our analysis is based on the market share of lead underwriters. Because they are chosen by the issuer and they are responsible for pricing and certifying the offering, it is the lead underwriter's reputation which is at stake.

${ }^{2}$ According to Dealogic, estimated global debt, equity and equity-related fees totaled US $\$ 44$ billion during the full year of 2014 and US $\$ 38.4$ billion in 2015 .

${ }^{3}$ The industry has underlined the growing weight of "capital light" activities such as underwriting in the financial press. See e.g. D. Schäfer and T. Alloway's February 21, 2013 Financial Times article "Mid-tier banks threaten the bulge bracket" and L. Noonan's December 14, 2015 article "Regulatory changes force investment banks into capital light activities".
} 
conditions for accessing capital markets may be negatively affected when underwriting competition among banks is distorted. However, no empirical evidence regarding this issue is available.

This paper aims to determine whether bailouts affect banks' competition in the underwriting business. This is an important research question because - together with the growing strategic importance of this business for banks - the way in which the underwriting industry operates has implications for bank reputation (Beatty \& Ritter, 1986; Carter \& Manaster, 1990; Fernando, Gatchev, \& Spindt, 2005). Reputation acts as a certification signal in debt markets. A large body of literature argues that reputation can be proxied by an underwriter's market share (Fang, 2005; Gande, Puri, Saunders, \& Walter, 1997; McCahery \& Schwienbacher, 2010; Megginson \& Weiss, 1991; Schenone, 2004). Thus, the reputational implications of being bailed out may impact banks' market shares. We address this question by examining the effects of bailout programs on banks' market shares as underwriters, employing a difference-in-differences (DID) analysis.

Our approach differs from the existing literature on bank bailouts and underwriting. Previous research has shown that bailouts may affect banks' market shares (Allen, Carletti, \& Marquez, 2011; Berger \& Bouwman, 2013; Berger \& Roman, 2015). Additionally, research on underwriting has emphasized the certification role of underwriters. Banks with ex-ante large market shares - considered within the industry as reputable - are aware that poor underwriting performance may damage their reputation and decrease their market share in the underwriting business (Booth \& Smith, 1986; Carter, Dark, \& Singh, 1998; Chemmanur \& Fulghieri, 1994; Dong, Michel, \& Pandes, 2011). Combining these two strands of literature, we hypothesize that bank bailout programs are likely to affect underwriting market shares, but the effects may differ depending on the ex-ante market share and reputational capital of the bailed-out bank. 
Our analysis contributes to the extant literature on bank bailouts by explaining the potential unintended effects of bailout programs on the underwriting business. Additionally, this paper contributes to the underwriting literature by exploring how certification-reputational concerns may affect underwriters' market shares following public recapitalization.

The empirical analysis relies on a panel of 121 underwriters active in the European corporate bond markets during the 2006-2013 period. Unlike previous studies, the analysis is not focused on a specific bailout program (e.g. the Troubled Asset Relief Program, TARP). We consider all the bailout programs that affect the sample of active underwriters. This is justified by the fact that banks from all over the world compete in this market, making the European underwriting industry less concentrated and more competitive than that in the US ${ }^{4}$. Although a certain degree of fragmentation in European initial public offering (IPO) markets has been shown (Vismara, Paleari, \& Ritter, 2012), we provide evidence of a non-fragmented European underwriting industry for corporate bonds.

Additionally, in the DID analysis, we control for the financial strength of the bank. We also account for specific quantitative and qualitative factors that drive underwriting market shares. Furthermore, we employ bond-level data to examine the firm-bank matching, which allows us to observe changes in underwriting volumes between each bailed-out underwriter and firm pair.

By way of preview, we find that those banks with large market shares, considered in the industry as reputable underwriters, suffer decreases in their underwriting market share (of $12.43 \%$ on average) after being bailed out. However, those with smaller market

\footnotetext{
${ }^{4}$ According to Dealogic, during the period 2003-2013, the Herfindal-Hirschman Index (HHI) for corporate bonds in the European underwriting industry was 0.4, while in the US it was 0.8. Similarly, the ten largest underwriters in Europe represent $56 \%$ of the market, while in the US they account for $82 \%$.
} 
shares, considered as non-reputable underwriters, increase their market share after being bailed out (of $36.28 \%$ on average). These results are confirmed by the firm-bank matching analysis. In particular, we find that reputable bailed-out banks experience market shares' losses since then are $2.4 \%$ less likely to win new mandates and $26.3 \%$ less likely to retain prior mandates. Conversely, less reputable bailed-out banks are $9.3 \%$ more likely to be chosen in new mandates and 5\% for more likely to retain prior mandates. Our results are found to be robust to different reputation measures, identifications, intensities of government support, endogeneity concerns and self-selection biases.

The remainder of the paper is organized as follows. Section 2 reviews the related literature. The hypotheses and research questions are presented in Section 3. Section 4 describes the data and methodology. The empirical results are presented in Section 5. Section 6 examines the firm-bank underwriting matching. Section 7 provides additional results considering alternatives measures of underwriters' reputation. Section 8 offers robustness checks and Section 9 concludes.

\section{RELATED LITERATURE}

\subsection{The impact of bank bailout programs}

Previous research has examined the determinants of whether a bank will be bailed out and the effects thereof. A primary and expected finding is that the financial health of the bank is a determinant of whether it will be bailed out (Bayazitova \& Shivdasani, 2012; Cornett, McNutt, Strahan, \& Tehranian, 2011; Gerhardt \& Vennet, 2017). Beccalli \& Frantz (2016) find that public bailouts occur for larger but less liquid banks that operate in large banking sectors. Similarly, Zanzalari (2015) shows that banks are more likely to be bailed out if they have low Tier-1 capital ratios, low ROAs and large exposure to real estate markets. In the case of TARP, it has also been found that political connections may affect the likelihood of a bank receiving public funds (Bayazitova \& Shivdasani, 2012; 
Berger, Makaew, \& Roman, 2018; Berger \& Roman, 2015, 2017; Duchin \& Sosyura, 2014; Li, 2013).

A number of studies have also explored the impact of bank bailouts on competition. The role of capital in bank competition has been widely studied, both theoretically and empirically (see for example Allen et al., 2011; Berger \& Bouwman, 2013; Koetter \& Noth, 2016). An increase in bank capital may generate a competitive advantage, distorting the level of competition. Previous studies have found that public capital increases have a positive effect on banks' market shares or ability to compete. Berger \& Roman (2015) show that beneficiaries of TARP in the US enjoyed a competitive advantage that led them to increase their loan market shares by $9.14 \%$. Similarly, Calderon \& Schaeck (2016) find that recapitalizations increased the market shares of "zombie banks" by 5\%. Koetter \& Noth (2016) also show competitive distortions as a result of TARP for non-TARP banks.

Some studies have examined the effects of public bailouts on lending. A number of these studies focus on credit supply at the extensive margin (credit quantities) and obtain mixed results. Li (2013) suggests that TARP investments increased banks' loan supplies (by an annualized rate of 6.36\%). Berger \& Roman (2017) also find an increase in banks' credit supplies, especially in commercial real estate lending. Berger, Makaew, \& Roman (2018) suggest that the probability of banks issuing loans increased during the post-TARP period. However, Duchin \& Sosyura (2014) and Bassett, Demiralp, \& Lloyd (2017) do not find any effects of public bailouts on credit supply. As for the intensive margin (credit conditions of the loans granted to borrowers), Berger, Makaew, \& Roman (2018) find that TARP banks grant loans with more favorable terms, i.e. lower interest rate spreads, larger amounts, longer maturities, less frequency of collateral and less restrictive covenants. 
Some related studies have examined the effects of bailout programs on bank risktaking (Black \& Hazelwood, 2013; Duchin \& Sosyura, 2014; Hakenes \& Schnabel, 2010; Li, 2013), financial stability (Berger, Roman, \& Sedunov, 2019), liquidity creation (Berger, Bouwman, Kick, \& Schaeck, 2016) and banks' stocks valuation (Bertsatos, Sakellaris, \& Tsionas, 2017; King, 2019; Liu, Kolari, Kyle Tippens, \& Fraser, 2013; Veronesi \& Zingales, 2010).

\subsection{Banks' underwriting role in capital markets}

Banks perform an intermediary function as underwriters, mitigating information asymmetries between insiders and outsiders. Underwriters do not merely distribute securities among investors; they perform a number of functions, including marketing, certification and screening (Dong et al., 2011).

Some theoretical contributions have shown that the underwriting function of commercial and investment banks is linked to their reputation (Beatty \& Ritter, 1986; Booth \& Smith, 1986; Carter \& Manaster, 1990; Chemmanur \& Fulghieri, 1994). The socalled "certification hypothesis" argues that underwriters certify the intrinsic value of an issuance due to their reputation (Beatty \& Ritter, 1986; Carter, Dark, \& Singh, 1998; Chemmanur \& Fulghieri, 1994; Dong, Michel, \& Pandes, 2011). Reputational concerns partially explain underwriters' avoidance of opportunistic behavior that could negatively affect their reputation. These same concerns discourage underwriters from misusing private information to improve their short-term performance. Reputable underwriters implement standards to assess the quality of issuers in order to prevent poor future performances (Chemmanur and Fulghieri, 1994). Thus, reputation-as an intangible long-term asset—may fluctuate over longer or shorter periods of time as a result of shocks that affect bank performance. 
Additionally, underwriter reputation explains how firms and underwriters are matched (Carbó-Valverde, Cuadros-Solas, \& Rodríguez-Fernández, 2017; Drucker \& Puri, 2005; Fernando, Gatchev, May, \& Megginson, 2015; Fernando, Gatchev, \& Spindt, 2005; Ljungqvist, Marston, \& Wilhelm, 2006; Yasuda, 2005, 2007), why underwriters are replaced in subsequent offerings (Humphery-Jenner, Karpavicius, \& Suchard, 2018; Krigman, Shaw, \& Womack, 2001) and why issuers prefer to engage with reputable underwriters (Burch, Nanda, \& Warther, 2005; Fang, 2005; Fernando, May, \& Megginson, 2012; McCahery \& Schwienbacher, 2010; Neupane \& Thapa, 2013). Thus, the literature on capital markets agrees that reputation plays a central role in the underwriting business.

In addition, there is general consensus that reputability assists in capturing market share. All market participants-issuers, investors, analysts, rating agencies and underwriters - recognize reputable underwriters as those with large market shares. This is primarily because third-party perceptions of reputation attract business. More reputable underwriters attract more underwriting contracts, which consequently leads to growth in their market shares ${ }^{5,6}$. Reputable underwriters are prominent participants in the bond market, which is consistent with the existence of a positive relationship between market share and reputation (Dunbar, 2000). Furthermore, the consistency of market share in the financial markets as a measure of reputation is supported by the use of this measure in the syndication loan market for lead arrangers (Sufi, 2007) and for advisors in mergers and acquisitions (Rau, 2000).

\footnotetext{
${ }^{5}$ Beatty \& Ritter (1986) relate reputation and market share, arguing that underwriters that place deals with initial returns inconsistent with their ex-ante uncertainty subsequently lose market share.

${ }^{6}$ Market share was first used to measure reputation in a seminal paper of Megginson \& Weiss (1991), leading to the so-called "MW measure". Megginson \& Weiss highlight the consistency of their measure, as it was found to be strongly positively correlated to the Caster-Manaster measure.
} 


\section{THE IMPACT OF BANK BAILOUTS ON UNDERWRITING MARKET}

\section{SHARES}

In order to analyze the impact of bailouts on banks' underwriting market shares, it is important to simultaneously consider the channels through which public capital infusions affect market shares and the certification-reputational concerns that exist within the underwriting industry.

\subsection{Channels through which bailouts affect market share}

Following Berger \& Roman (2015), there are some channels through which banks' market shares in the underwriting business may increase or decrease. Strengthening banks' capital may generate a competitive advantage that would lead beneficiaries of state aid recapitalization measures to increase their market shares due to a predation, a safety or a cost-advantage channel. The predation channel allows bailedout banks to use capital infusions to compete more aggressively by offering better conditions, thus increasing their market shares. The safety channel is based on the constant scrutiny from the public sector that is a consequence of being bailed out. Public scrutiny would reduce bank risk-taking, so that recapitalized underwriters are perceived as "safer" (i.e. less likely to repeat poor performances in future). Consequently, firms may contract the underwriting services of recapitalized banks due to their perceived safety. Finally, the cost-advantage channel is founded on banks' perceptions of the capital received as having a lower cost. This may lead banks to take advantage of these relatively costless funds to expand their businesses.

Bailed-out banks may also suffer market share losses. This may happen because banks, seeing their survival at stake, may adopt a less aggressive strategy, which would result in lower market shares (the 'quiet life' or risk-averse channel). Alternatively, a stigma channel may operate, which is the opposite of the safety channel. Specifically, 
being bailed out may generate a negative signal regarding the resilience of the bank, which may make firms reluctant to request a bailed-out bank's services. Finally, a costdisadvantage channel may operate when banks perceive the funds received to be costly, which would lead bailed-out banks to downsize their businesses.

There is empirical evidence of the positive effects of bailouts on the extensive margin of credit supply (Berger, Makaew, \& Roman, 2018; Berger \& Roman, 2017; Li, 2013). Furthermore, Berger \& Roman (2015) find that bailed-out banks increase their lending market shares after receiving TARP funds. They suggest that their results are driven primarily by the safety channel.

\subsection{The certification-reputational channel in the underwriting industry}

Reputation is a valuable asset for underwriters, as their credibility as certifiers relies on it. Poor performances negatively affect the future volume of underwriting business (Booth \& Smith, 1986; Carter \& Manaster, 1990). There is evidence that declines in market share can be attributed to losses in reputational capital. For example, the scandal involving Salomon Brothers' bond business led the bank to lose market share in the underwriting industry (Smith, 1992). Beatty, Bunsis, \& Hand (1998) show that it is not only consummated scandals that negatively affect banks' market shares; it is enough to be publicly targeted as a subject of formal investigation. Similarly, and more recently, Hanley \& Hoberg (2012) find that underwriters that have been the target of a lawsuit experience market share declines. Reputational concerns have also been found to lead banks to reject a recapitalization offer (Corbett \& Mitchell, 2000). Banks are aware of the stigma attached to participating in government programs, as this participation could mean admitting financial weakness (Philippon \& Skreta, 2012). It has also been shown that 
during a period of financial turmoil, trust in banks declines ${ }^{7}$, which may lead to a more severe loss of trust for troubled banks (Sapienza \& Zingales, 2012). Bank customers response to government interventions (Hasan, Jackowicz, Kowalewski, \& Kozłowski, 2013; van der Cruijsen \& Diepstraten, 2017). Diepstraten \& Cruijsen, (2019) find that current account holders of the recapitalized bank are more likely to switch away shortly after the bail-out. In the banking industry, Fiordelisi, Soana, \& Schwizer $(2013,2014)$ document reputational losses in Europe and North America following operational losses.

In a similar vein, investors' reactions to reputational shocks for credit rating agencies, which also play a role in mitigating information asymmetries, have been documented in several crises (Bedendo, Cathcart, \& El-jahel, 2018). Hence, in the banking industry, and especially in the underwriting industry, third parties seem to penalize financial institutions when they behave inappropriately.

\subsection{Ex-ante reputational capital}

The impact of state aid measures on a bailed-out bank's market share may differ depending on certain ex-ante characteristics of the bank. Black \& Hazelwood (2013) and Berger \& Bouwman (2013) find that public capital injections generate different effects for large and small banks. Small and less reputable banks use bailout funds to increase lending and market share, leading to a competitive advantage for them. Dunbar (2000) and Ljungqvist et al. (2006) suggest that large and well-established banks are more exposed to losses in reputational capital. In a similar vein, Gopalan, Nanda, \& Yerramilli (2011) find different effects for large and small lead arrangers in the syndicate loan market, which they interpret as a key difference in the way in which the reputation mechanism operates.

\footnotetext{
7 There are some studies on the distrust of banks during the financial crisis. Carbó-Valverde, Maqui-López, \& Rodriguez-Fernandez (2013) examine the Spanish banking system, Mosch \& Prast (2008) the Dutch banking system and Knell \& Stix (2009) the Austrian banking system.
} 
Hence, reputational capital is not distributed homogeneously among underwriters. Some are perceived as reputable, while others are not. Thus, while there is a certificationreputational channel in the underwriting industry, it may affect banks differently depending on their ex-ante reputational capital. Consequently, the impact of bailout measures would differ for highly reputable banks (with large market shares) and for less reputable banks (with smaller market shares). The changes in the market shares of recapitalized underwriters from 2008 onwards, shown in Figure II, seem to reveal different patterns depending on the underwriters' prior reputations.

Banks with large underwriting market shares may experience a decrease in their market share, because they have more to lose due to their greater reputational capital. Such decreases may occur because the certification-reputational channel would outweigh other channels. However, for less reputable banks that do not have significant ex-ante reputational capital, a public capital injection may act as a competitive advantage. Thus, the effect of public scrutiny leading them to be perceived as safer may lead them to increase their market share.

\section{DATA AND METHODOLOGY}

\subsection{Data and descriptive statistics}

Our primary data source is a sample of underwriters that issue fixed corporate bonds, obtained from the Dealogic Debt Capital Markets database. The sample excludes deals issued by utilities and regulated firms (SIC: 4000s) and financial firms (SIC: 6000s). The time period is 2006-2013, which allows us to explore the effects of the banking crisis, in addition to covering all of the bailout programs undertaken as a consequence thereof. We match each bank with the information on its accounting statements provided by Bankscope. We also account for the lender-borrower connection of each underwriter by 
using Thomson ONE to obtain information on their lending activity. The final sample includes 121 bond underwriters.

We follow the methodology employed in Huyghebaert \& Xu (2015) to deal with mergers and acquisitions that took place during the sample period. Merger information was collected from Bankscope, Lexis-Nexis and banks' own information sources ${ }^{8}$. If one underwriter has acquired another bank, we use different codes for the acquired bank and the acquirer before the acquisition, while the acquiring bank's code is used after the acquisition. If two banks have merged to form a new bank, we employ a different code for the bank created after the merger. Finally, for name changes in which no merger or takeover were involved, we use the same code for the bank before and after the name change.

Table I indicates the yearly distribution of our panel of underwriters, as well as the top five underwriters by market share. We consider an underwriter as active in a particular year if it placed at least one deal during that year. Our data indicate that the number of active underwriters rose from 38 in 2006 to 94 in 2013. Furthermore, the league table rankings are topped each year by well-established banks, namely Deutsche Bank, Barclays, JP Morgan, HSBC, Citi, BNP Paribas, RBS and Société Générale. Finally, it is shown that the average market share fell from $2.69 \%$ in 2006 to $1.10 \%$ in 2013.

As far as we know, there is no updated database listing all the financial institutions that were bailed out during the recent financial crisis. The data are dispersed, since these measures were adopted by different national governments and supranational institutions according to their respective competencies. Therefore, we manually collected data from several sources, depending on the nationality of the underwriter:

\footnotetext{
${ }^{8}$ We identify prior lending and underwriting relationships accounting for mergers between underwriters. For example, for Bank of America's acquisition of Merrill Lynch on January 1, 2009, we use different codes for the acquired bank and the acquirer before the acquisition. As of the acquisition date, the resulting entity Bank of America Merrill Lynch absorbs all relationships from both predecessor banks.
} 
- EU underwriters: Data source: European Commission, State Aid Control. The European Commission has a State Aid Control Section, which is primarily integrated by the Directorate-General for Competition ${ }^{9}$. All state aids are publicly viewable through a multi-criteria search tool that provides access to all the cases that have been the objects of a Commission decision since 1 January $2000^{10}$. Using this tool, we tracked all the state aids granted in the EU to financial firms during the research period (K.64 Financial service activities).

- U.S. underwriters: Data source: Emergency Economic Stabilization Act TARP, U.S. Department of the Treasury. In October 2008, the U.S. Congress authorized TARP, allocating a maximum of US\$700 billion to buy assets and equity from financial institutions with the aim of increasing the stability of the financial sector. We tracked all the programs ${ }^{11}$ approved under TARP in order to determine which U.S. banks were bailed out during the research period.

- Swiss underwriters: Data source: Swiss National Bank (SNB).

- Other underwriters: Data source: Publicly available data sources (central banks, governments, bank websites, treasuries and restructuring agencies).

Following earlier studies, we generate annual dummies, which take the value 1 if the underwriting bank received an injection of equity from the state considered as eligible Core Tier 1 Capital. In the Appendix, Table B describes all the recapitalization processes

\footnotetext{
${ }^{9}$ Article 107 of the Treaty on the Functioning of the European Union (TFEU) contains a general prohibition of state aids in order to not distort competition and trade within the EU. However, under some circumstances, governments can intervene to offset market failure. With the aim of controlling these aids, the European Commission created the State Aid Control Section.

${ }^{10} \mathrm{http}: / /$ ec.europa.eu/competition/elojade/isef/index.cfm

${ }^{11}$ Programs approved under TARP include the Capital Purchase Program (CPP), the Automotive Industry Financing Program (AIFP), the AIG Investment Program, the Targeted Investment Program (TIP), the Mortgage Loan Modification Plan, the Public-Private Investment Program (PIP), the Housing Finance Agency Innovation Fund, the Federal Housing Administration Refinance Program, the Community Development Capital Initiative (CDCI), the Auto Supplier Support Program, the Small Business and Community Lending Initiative, the Term Asset-Backed Securities Loan Facility (TALF), the Asset Guarantee Program (AGP), the Securities Purchase Program, the Supervisory Capital Assessment Program (SCAP) and the Capital Assistance Program (CAP).
} 
implemented amongst our sample of underwriters ${ }^{12}$. We report 64 recapitalization measures from 2006-2013, concerning 36 banks and a total amount of over $€ 350$ billion. As some banks were recipients of more than one recapitalization measure during the same natural year, we ended up with 55 year-recapitalization observations. As expected, most of these recapitalizations took place during the period starting in September 2008, after the collapse of Lehman Brothers, and ending in December 2010. During this period, the structural deficit in the Eurozone reached $15 \%$ of GDP, and the European sovereign debt crisis began. After December 2010, only amendments to previously approved recapitalization measures were made, as Table B.I shows.

Table II provides definitions and summary statistics for the variables. As could be expected, this table shows that bailed-out banks are larger in size, less profitable and less liquid.

\subsection{Empirical modelling}

The effects of bailout measures on underwriters' market share are examined using a DID analysis. The aim is to compare the evolution of the market shares of state-aidrecapitalized underwriters and non-recapitalized underwriters. Recent studies have used a similar approach to examine the effects of state capital injections in the banking sector (Berger et al., 2018; Berger \& Roman, 2015, 2017; Black \& Hazelwood, 2013; Duchin \& Sosyura, 2014; Montgomery \& Takahashi, 2014; Nakashima, 2016; Poczter, 2016). By employing this approach, we control for observable and unobservable factors that affect both groups of banks.

In line with prior studies (Berger et al., 2018; Berger, Roman, \& Sedunov, 2019; Berger \& Roman, 2015; 2017; Duchin \& Sosyura, 2014; Montgomery \& Takahashi,

\footnotetext{
${ }^{12}$ For example, the German bank HSH Nordbank was recapitalized in 2008 and 2009, but it does not appear on the list because it did not place any corporate bonds during the 2007-2013 period.
} 
2014), our treatment group consists of underwriters that received state aid equity during the period starting with the collapse of Lehman Brothers (September 2008). The treatment period encompasses the entire TARP program in the US, as well as the bulk of the recapitalization programs in Europe.

Since some banks were recapitalized repeatedly during our sample period, we examine the effects of state aid recapitalization on underwriters' market share using a generalized DID approach that deals with multiple events (bailouts). This approach, employed in Bertrand and Mullainathan's (2003) seminal paper and subsequently used in several studies (Chen \& Vashishtha, 2017; Fang, Hasan, \& Marton, 2014; Francis, Hasan, John, \& Waisman, 2010; Haselmann, Pistor, \& Vig, 2010), addresses many threats to the validity of our analysis. We estimate the following equation (1):

Mkt. Share ${ }_{i t}=\alpha+\beta_{1}$ Recapitalized $_{i t}+\beta_{2} X_{i t-1}+\beta_{3}$ Time $_{t}+\beta_{4}$ Underwriter $_{i}+\varepsilon_{i t}$

The dependent variable is the market share of underwriter $i$ in year $t$. Recapitalized $_{\mathrm{it}}$, is an indicator variable equal to 1 when and after a bank $i$ receives a public capital injection at year $t$, and 0 otherwise. This variable serves as the DID operator with precise timing of the bailouts of each bank. This methodology fully controls for fixed differences between treated and non-treated banks via the underwriter fixed effects, removing biases that could be due to other omitted time-invariant factors rather than bailouts. We also include time fixed effects to control for aggregate fluctuations in market shares over time. In particular, this generalized DID approach allows us to account for the fact that some banks were recapitalized strictly before December 2010 (e.g. those recapitalized through TARP funds) while others (e.g. some of the European banks) were recapitalized repeatedly before and after December 2010. Moreover, by employing this methodology, no bank is excluded from the analysis on the grounds that they were recapitalized later. 
In order to explore how the bailout effect on market share varies depending on the underwriter's ex-ante reputation level, we employ the following equation (2): Mkt. Share $_{i t}=\alpha+\beta_{1}$ Recapitalized $_{\mathrm{it}} \mathrm{x}$ Reputable $_{\mathrm{i}}+\beta_{2} \mathrm{X}_{\mathrm{it}-1}+\beta_{3}$ Time $_{\mathrm{t}}+\beta_{4}$ Underwriter $_{\mathrm{i}}+\varepsilon_{\mathrm{it}}$

An underwriter is considered Reputable $e_{i}$ if it ranks among the top five underwriters based on market share, and it equals zero otherwise. Following prior studies (Andres, Betzer, \& Limbach, 2014; Fang, 2005; Livingston \& Miller, 2000; McCahery \& Schwienbacher, 2010; Narayanan, Rangan, \& Rangan, 2006; Yasuda, 2005), we use a discrete measure based on market share to identify highly reputable underwriters. As Fang (2005) argues, this measure best captures the market structure, because banks in capital markets are commonly seen as either heavyweight players or not. Given the aim of the test, in order to classify an underwriter as reputable, we use the pre-bailout (or pretreatment) period market shares. Using market share measured at any point during the post-treatment (post-bailout) period would be inappropriate, given that our aim is to measure ex-post changes in market share during the post-bailout period relative to the pre-bailout period. Pre-bailout market shares are computed on annual proceeds raised in the corporate bond markets from 2006 to September 2008 (before the collapse of Lehman Brothers as the triggering event of the financial crisis) ${ }^{13}$. Then, the interaction Recapitalized $_{\mathrm{it}} \mathrm{x}$ Reputable $_{\mathrm{i}}$ is the DID term, which takes the value 1 when and after the underwriter received a bailout and the underwriter ranks among the top five underwriters based on the pre-bailout market shares. In equation (2), the firm fixed effects capture prebailout differences that may affect underwriter reputation.

\footnotetext{
${ }^{13}$ According to their pre-bailout market shares, Deutsche Bank, RBS, JP Morgan, HSBC and Citi are ranked in the top five positions during the pre-bailout period.
} 
Furthermore, the standard errors reported are robust to heteroscedasticity. Since the variance of the error term may be larger for reputable underwriters with larger market share than it is for less reputable underwriters with smaller market share, we cluster the standard errors by underwriter.

\subsection{Variables}

\subsubsection{Dependent variable: Market share}

Market shares are computed on a proceeds base, in which the proceeds of syndicated bonds are divided among all the underwriters. One concern about using market shares in Europe could be the existence of a fragmented market at a national level, as Vismara et al. (2012) find for IPOs. In this sense, the presence of national local underwriters that operate almost exclusively in a single country would bias our result, because their reputation would be high in their domestic market, but lower abroad. Although European debt markets seem to be less fragmented than European IPO markets, we address this issue. In order to detect possible bias, we compute bonds denominated in the national currency of the issuer, underwritten by domestic banks and sold into the domestic market. In general, as Table A.I reveals, while IPOs are chiefly domestic deals placed by a single underwriter, bonds are typically marketed internationally by a syndicate. In our sample, domestic bonds represent just $4 \%$ of proceeds and $12 \%$ (288 bonds out of 2,457) of the total number of deals. Domestic bonds are smaller in size on $\operatorname{average}^{14}$.

Furthermore, following Migliorati \& Vismara (2014), we compute the national rankings for the core European economies (Germany, the United Kingdom, France, Italy, and Spain), with the aim of detecting whether there are national local underwriters (banks

\footnotetext{
${ }^{14}$ In our sample, the average issue size of domestic bonds is $\$ 157.69$ million, while for non-domestic bonds the average size is $\$ 565.61$ million.
} 
with large market shares in their domestic markets but small market shares at the European level). Table A.I provides a per-country overview of all the underwriters with a global market share lower than $1 \%$. These underwriters have small market shares in both international and domestic markets ${ }^{15}$.

We also perform a matched-pairs t-test on means equality ${ }^{16}$ across national markets, and we do not find evidence of significant differences. Large differences across national markets would likely lead to differences in market structure. Thus, we compute the Herfindahl-Hirschman Index for each market. No noticeable differences among markets are found.

\subsubsection{Explanatory variables}

\subsubsection{Determinants of underwriters' market shares}

Together with variables reflecting the financial strength of the bank, we control for specific quantitative and qualitative factors that drive underwriting market shares. The effects of several quantitative and qualitative determinants on market share changes in the US are examined in Dunbar (2000). Furthermore, Liu \& Ritter (2011) present empirical evidence in support of their theoretical predictions of issuers' willingness to receive pricing (quantitative) and non-pricing (qualitative) underwriting services. As for debt issues, Ang \& Zhang (2004) also provide evidence of pricing and non-pricing competition among underwriters, while in the equity markets Fernando et al. (2015) find differences in prices and the services provided depending on the underwriter's reputation. Chen, Shi, \& Xu (2014) and Huyghebaert \& Xu (2015) show that non-pricing factorsthe quality of the services provided and public ownership_influence market shares in

\footnotetext{
${ }^{15}$ For example, we can see that the largest market share in a domestic market—held by the Italian bank Mediobanca, $3.42 \%$ - does not place this bank high in the Italian ranking. Moreover, Mediobanca has a presence in other markets, such as the French and German markets.

${ }^{16} \mathrm{H}_{0}$ : $\mu_{\text {country }}=\mu_{\text {Europe }} ; \mathrm{i}=$ France, Germany, the United Kingdom, Italy, and Spain.
} 
China, while Migliorati \& Vismara (2014) also consider these factors as determinants of the underwriting rankings in the main European stock markets.

As for pricing factors, following the most closely related studies on underwriters' market shares (Dunbar, 2000; Huyghebaert \& Xu, 2015), we build a variable called abnormal fees in order to account for a pricing strategy. Using Ordinary Least Squares (OLS), we run annual regressions considering all fees charged in a three-year rolling window as dependent variable ${ }^{17}$. Using the coefficients of these regressions, we obtain predicted fees, which are then subtracted from the observed fees. Finally, for each underwriter, we compute the average abnormal fees charged in a three-year window using the underwriter's gross proceeds as weighting factor. In a similar vein, we build a variable called abnormal spread ${ }^{18}$ to control for underwriters' bond valuations. ${ }^{19}$

As for qualitative factors, we control for the quality of the underwriter's research team by employing the variable number of total star analysts based on the Institutional Investor awards ${ }^{20}$. A positive relationship between analyst reputation and research quality is assumed (C. Chen et al., 2014; L. H. Fang \& Yasuda, 2014; Krigman et al., 2001). Furthermore, we also account for banks' lending arms with the variables $U W$ Lender and Lending Market Share. This is because banks currently offer lending and underwriting services simultaneously, and there could be cross-service complementarities (Corwin \& Stegemoller, 2014; Duarte-Silva, 2010). Additionally, the underwriters' degree of specialization in issuing bonds in a specific industry could affect their market shares.

\footnotetext{
17 Table A.II reports the empirical modelling conducted to compute abnormal fees. The results of the estimations are not shown to conserve space, but are available upon request.

${ }^{18}$ Table A.II reports the empirical modelling conducted to compute abnormal spreads. The results of the estimations are not shown to conserve space, but are available upon request.

${ }^{19}$ Alternatively, for robustness purposes, we computed abnormal fees and abnormal spreads using a two-year window in unreported regressions. Similar results were obtained.

${ }^{20}$ The magazine Institutional Investor surveys 21 sectors and identifies the top-ranked analysts. The ranked analysts are divided into several categories: first, second, third and runner-up.
} 
Hence, we control for underwriters' industry specialization by computing a HerfindahlHirschman index for each underwriter (HHI Industry specialization).

We also include a further set of controls with the aim of accounting for additional deal and underwriter features to ensure that the main results do not hinge upon the omission of variables. We control for private placements with the weighted ratio of placement deals, since being highly active in placing these deals may reflect a capacity to attract sophisticated investors who could also attract issuers. Additionally, we control for multiple underwritten deals with the weighted ratio of these deals.

\subsubsection{Determinants of underwriters' financial health}

We employ a set of financial ratios to account for the different dimensions of the underwriter: size, profitability, liquidity, efficiency and capital adequacy. We also control for underwriters' experience by taking into account the number of years since their first placement, as well as whether they are listed on a stock exchange ${ }^{21}$.

\section{RESULTS}

\subsection{Difference-in-differences (DID) results}

The DID estimations are presented in Table III. Columns 1 and 2 report the results for the regression of Equation 1, while Columns 3 and 4 present the results for Equation 2. For Equation 1, we find that Recapitalized $d_{i t}$ is positive but not statistically significant. Compared to non-recapitalized banks, recapitalized banks did not increase their market share after receiving state aid. However, this result should be complemented with the findings for Equation 2, in which the effect of being recapitalized on market share is separated from underwriter reputation. We find that the coefficient of Recapitalized it is

\footnotetext{
${ }^{21}$ All the variables are described in Table A.II. Panel C.
} 
positive and statistically significant, while the coefficient of Recapitalized $_{i t} x$ Reputable $_{i}$ (for reputable underwriters) is negative and statistically significant. These results indicate a differential effect of state aid recapitalization depending on underwriter reputation. As it could be observed, the impact of a bank bailout for a reputable underwriter is negative since the sum of both coefficients remains negative. While reputable recapitalized underwriters suffered losses in their market shares after state aid recapitalization, nonreputable recapitalized underwriters increased their market shares after receiving state aid. Therefore, the effect of state aid depends on the underwriter's prior reputation level. Reputable underwriters' losses in market share are consistent with a certificationreputational hypothesis. Underwriters with ex-ante large reputational capital are more likely to lose market share after recapitalization. Conversely, those underwriters that do not have large ex-ante reputational capital use recapitalization as a competitive advantage.

These results are economically meaningful, since a reputable recapitalized underwriter experiences a $12.43 \%$ decrease in its market share from its average market share. At the same time, the average market share of a non-reputable recapitalized underwriter increases by $36.28 \%$ following recapitalization.

Turning to the determinants of underwriters' market shares, the results obtained show that market shares are not driven by price-based competition, as the coefficient of abnormal fees and abnormal spreads are non-significant. Interestingly, the impact of lending on underwriting market shares is also indicated by the positive and significant coefficients of $U W$ Lender. Furthermore, hiring star analysts for the underwriting team significantly increases underwriters' market shares, since the coefficient of number of star analysts is positive and statistically significant. These findings are consistent with underwriters with large market shares (which are considered reputable) offering highquality underwriting services. 


\section{FIRM-BANK UNDERWRITING MATCHING: BOND-LEVEL DATA}

In order to ensure that the impact of state aid measures on a bailed-out bank's underwriting market share differs depending on the bank's ex-ante reputational capital, we also examine the firm-bank underwriting matching. By using bond-level data we are able to examine the change in the underwriting volumes between each underwriter-firm pair. In doing so, we control for firm characteristics (demand-side factors) and firm fixed effects to absorb the change in firms' demand in issuing bonds, as well as underwriterspecific characteristics (supply-side factors). This approach has also been employed in the banking literature (Khwaja \& Mian, 2008; Schnabl, 2012). If, as we hypothesize, bailout programs affect underwriting market shares depending on the ex-ante reputational capital of the bailed-out bank, the firm-bank matching analysis should show that the likelihood of being appointed as underwriter decreases for more reputable bailed-out banks and increases for less reputable bailed-out banks after controlling for demand and supply factors.

To conduct this analysis, we collect the bond-level data on fixed corporate bonds from the Dealogic Debt Capital Markets database. This comprises 1,611 deals issued by 323 firms during the period 2006-2013. Using Compustat Global, we obtain the key accounting information for each bond issuer. Furthermore, we identify prior firm-bank relationships using Dealogic and Thomson ONE. This provides a unique sample with detailed information about bond characteristics, firm characteristics, bank characteristics and prior firm-bank relationships.

\subsection{Firm-bank matching: Winning a mandate}

In order to address the firm-bank matching, we build a model of the decision to choose a bank as bond underwriter from a set of potential underwriters. The choice set includes all banks that underwrote at least one bond in the year of the bond issuance. 


$$
\begin{aligned}
& \mathrm{E}(\mathrm{Y} \mid \mathrm{X}=\mathrm{x})=\operatorname{Pr}(\text { Chosen } U W=1 \mid \mathrm{X})=\Lambda\left(\beta_{0}+\beta_{1} \text { Recapitalized Bank }+\beta_{2} \text { Reputable }+\right. \\
& \beta_{3} \text { Recapitalized } \mathrm{x} \text { Reputable }+\beta 4 X_{\text {bond }} \text { features }+\beta 5 X_{\text {firm features }}+\beta 6 X_{\text {bank }} \text { features }+ \\
& \left.\beta_{7} X \text { firm-bank relationships }+ \text { Year FE }+ \text { Firm FE }+e i\right)
\end{aligned}
$$

Our dependent variable is a dummy taking the value 1 if the bank is chosen among the set of potential underwriters. Following prior studies (Chen \& Vashishtha, 2017; Croci, Degl'Innocenti, \& Zhou, 2019; Dyck, Morse, \& Zingales, 2010; Hellmann, Lindsey, \& Puri, 2008; Kuhnen, 2009) and in order to avoid the incidental parameters problem when estimating a binary choice model with fixed effects, we use a conditional fixed effects logit model. By doing so, the estimations and the standard errors are consistent after including firm and year fixed effects ${ }^{22}$. All the variables that control for bond, firm and bank characteristics, as well as for prior firm-bank relationships, are defined in Table A.II in the Appendix.

Our main variables of interest are Recapitalized Rit $_{\text {and }}$ the interaction term Recapitalized $_{i t} x$ Reputable $_{i}$, which shows how the effect of being bailed out on the firmbank matching varies with the ex-ante reputational capital of the underwriter. The first set of control variables includes proxies for bond characteristics to account for possible effects of the structure of the bond (e.g. size, maturity, callability, etc.) on the choice of underwriter. The second set of control variables includes firm characteristics such as firm size, leverage, profitability and experience issuing bonds. By including these variables, we control for firms' demand in issuing bonds. Our third set of control variables captures variation in time-variant bank characteristics (supply-side factors). Finally, since firmbank relationships affect the likelihood of a firm being appointed as underwriter (Bharath, Dahiya, Saunders, \& Srinivasan, 2007; Corwin \& Schultz, 2005; Drucker \& Puri, 2005;

\footnotetext{
${ }^{22}$ For robustness purposes, we have also estimated a linear probability model (LPM) and a probit model without fixed effects but using a two-way clustering of standard errors by year and issuer. The results are robust across these alternative specifications.
} 
Duarte-Silva, 2010; Ljungqvist et al., 2006) we consider the two main relationships that a firm may have with a bank, namely those of bond underwriter and lender. Moreover, we include firm and year fixed effects to control for unobservable firm characteristics and variations in debt financing over time, respectively.

The results of the firm-bank matching are shown in Table IV. Taking together the coefficients and the statistical significance of Recapitalized Rit $_{\text {and }}$ Recapitalized $_{i t} x$ Reputable $_{i}$, we find that bailed-out banks are more likely to be chosen as underwriters, except when the bailed-out bank is highly reputable. Consistent with our expectations following the DID regressions, the effect of being bailed out on the firm-bank matching varies with the underwriter's ex-ante reputational capital. Furthermore, we also compute the predicted probability of the matching between firms and banks. We find that for reputable bailed-out underwriters, the probability of being chosen in a given deal decreases by $2.4 \%$, while this same probability increases by $9.3 \%$ for less reputable bailed-out underwriters. The positive effect of a bailout for non-reputable underwriters is stronger than the negative effect thereof for reputable underwriters. This result is in line with the larger increase in market share $(+36.2 \%)$ for non-reputable bailed-out banks compared to the decrease in market share $(-12.4 \%)$ suffered by reputable bailed-out banks, as shown in the DID regressions.

Furthermore, since bank bailouts occur during a period of economic difficulty, the firm-bank matching allows us to check that our estimates are not contaminated by other confounding events. First, it may be that during the crisis, some firms that are unable to obtain loans could increase the demand in issuing corporate bonds for financing purposes (Carvalho, Ferreira, \& Matos, 2015). In order to avoid potential biases stemming from the possibility that the restricted availability of other funding sources led some firms to issue corporate bonds during the crisis, we re-estimate our models for a subsample of 
firms that issued at least one bond in both periods: pre-crisis and crisis. Second, lending relationships on the credit market are strong predictors of underwriting relations between commercial bank underwriters and firms (Yasuda, 2005), especially in the European market. In order to test that changes in market shares are not partly driven by those firms that lost their lending relationships because of the crisis, we re-run the regressions for firms that did not take out a loan during any of the four years before the bond issuance ${ }^{23}$. Thus, the matching is not potentially affected by the existence of prior lending relationships. Columns 2 and 3 of Table IV shows the results, which are fully consistent with the baseline estimation.

\subsection{Firm-bank matching: Retaining a prior mandate}

We employ bond-level data to examine the probability of an underwriter retaining a prior mandate from a given firm. For each bond $\mathrm{k}$ issued by firm $\mathrm{i}$, we consider whether the firm has retained the prior underwriter(s). Then, for any given bond issued from September 2008 onwards (when the bulk of the recapitalization measures began), the choice set includes the bank(s) that underwrote the previous bond issued by the firm in question. Our dependent variable is a dummy taking the value 1 if the bank is retained as underwriter. Consistent with the methodology used in the examination of the firm-bank matching, we use a conditional fixed effects logit model to avoid the incidental parameter biases of including firm and year fixed effects. As in equation (3), we control for bond, firm, bank and prior firm-bank relationships. Moreover, we include firm and year fixed effects to control for unobservable firm characteristics and variations in debt financing over time, respectively. Then, we estimate the following equation (4):

\footnotetext{
${ }^{23}$ We also consider longer (five-year) and shorter (three-year) time windows in unreported regressions. The results remain robust.
} 


$$
\begin{aligned}
& \mathrm{E}(\mathrm{Y} \mid \mathrm{X}=\mathrm{x})=\operatorname{Pr}(\text { Retained } U W=1 \mid \mathrm{X})=\Lambda\left(\beta_{0}+\beta_{1} \text { Recapitalized Bank }+\beta_{2}\right. \text { Reputable } \\
& +\beta_{3} \text { Recapitalized } \mathrm{x} \text { Reputable }+\beta_{4} \mathrm{X} \text { bond features }+\beta_{5} X \text { firm features }+\beta 6 \text { Xbank features }+ \\
& \left.\beta_{7} X \text { firm-bank relationships }+ \text { Year FE }+ \text { Firm FE }+e i\right)
\end{aligned}
$$

The regression results are shown in Table V. Taking together the coefficient and the statistical significance of Recapitalized ${ }_{i t} \times$ Reputable $_{i}$, we find that reputable banks are less likely to be retained as underwriters when they are bailed out. This result suggests that reputable banks are more likely to be replaced as underwriters after being bailed out. These findings are in line with the hypothesis of a differential effect of ex-ante reputational capital. We find that for reputable bailed-out underwriters, the probability of retaining a mandate decreases by $26.3 \%$, while this same probability increases by $5 \%$ for less reputable bailed-out underwriters.

\section{MEASURING REPUTATION}

In order to ensure that reputation is appropriately measured we have considered alternative reputation indicators.

\subsection{Continuous measures of reputation}

In order to avoid potential biases introduced by the use of a discrete measure of reputation, we use continuous indicators and re-run our models ${ }^{24}$ Three continuous measures of reputation are considered. Firstly, we use each underwriter's total proceeds raised in the corporate bond markets during the pre-bailout period (UW-proceeds). With this measure, each underwriter is assigned a reputation based on the dollars it places into the bond markets. Moreover, we compute a variable based on the ranking held in the league tables (UW-inv.ranking). Specifically, we obtain the multiplicative inverse of the pre-bailout ranking position (e.g. if a bank is ranked third, the inverse ranking would be

\footnotetext{
${ }^{24}$ This measure is computed as $\mathrm{UW}-\mathrm{MW}_{\mathrm{j}, \text { pre-bailout }}=\frac{\ln \left(\text { proceed }_{\mathrm{j}, \text { pre-bailout }}\right)}{\max _{\mathrm{i} \in \mathrm{I}}\left(\ln \left(\operatorname{proceeds}_{\mathrm{i}, \text { pre-bailout }}\right)\right.} * 100$
} 
$1 / 3)$. This is a continuous variable on the interval $[0,1]$, where scores closer to 1 indicate higher reputability. Finally, we also use Megginson and Weiss' (1991) indicator (UWMW) of underwriter reputation. This is a market-share-based continuous variable ${ }^{254}$ on the interval $[0,100]$. All the reputation measures are strongly positively correlated. Table VI reports the results of the regressions employing all the continuous measures. Our main results, indicating a differential effect of state aid recapitalization depending on underwriter reputation, are confirmed.

\subsection{Alternative measures of reputation}

In order to avoid measurement errors and test the soundness of our results, we also employ alternative measures of underwriter reputation. Based on prior theoretical and empirical findings on underwriter reputation, we consider two alternative measures of reputation. Firstly, we use bonds placed for high-quality firms. Fernando et al. (2005) find evidence of a positive assortative selection between firms and underwriters, by which high-quality issuers match with reputable underwriters. Dai, Jo and Schatzberg (2010) also find a positive assortative matching in private investments in public equity markets (PIPE). We then build a reputation measure based on the bonds issued by high-quality firms during the pre-bailout period. To compute this measure, we consider the underwriters' market shares among those deals issued by firms that had a high grade or prime rating (above A+/A1) when issuing the bond. According to the standards reported by the main rating agencies, firms with such ratings are high-quality firms with very low credit risk due to their capacity to meet their financial commitments. Ratings at launch provided by the three main rating agencies (Standard \& Poor's, Moody's and Fitch) are considered. If the agencies' ratings differ, we consider a firm high quality if at least two 
agencies provided a rating above A+/A1. Reputation, based on these high-quality firms' bonds, is computed using discrete and also continuous measures.

Secondly, we also measure underwriters' reputation based on the accuracy/reputation of their fixed income investment analysts. Investment analysts play an important role in capital markets, as they may increase visibility among potential investors, reduce information asymmetries, and enhance liquidity (Autore, Kovacs, \& Sharma, 2009; Barth, Zasznik, \& McNichols, 2001; Jiraporn, Chintrakarn, \& Kim, 2012). Earlier studies have revealed a positive relationship between analyst reputation and research quality (Fang \& Yasuda, 2014; Fang \& Yasuda, 2009; Gleason \& Lee, 2003; Jackson, 2005). The accuracy of their forecasts allows analysts and their research teams to establish a reputation within the industry. Those analysts are known as "star analysts". The presence of star analysts is proxied by the Institutional Investor Awards (Abrahamson, Jenkinson, \& Jones, 2011; Drucker \& Puri, 2005; Fang \& Yasuda, 2009; Franck \& Kerl, 2013). Then, based on the All-Europe Fixed-Income Research Team awards, each bank has a reputation level in line with the total number of analysts' awards received during the pre-bailout period. Again, reputation is computed using discrete and continuous measures. Table VII reports the results. The baseline findings hold.

\subsection{The reputational cutoff}

In order to provide additional insight into the differential effect of bank bailouts depending on banks' ex-ante reputational capital, we consider some reputational cutoffs. Firstly, we re-run the DID regressions, extending the criteria used to define reputation (Top 5, Top 10, Top 15, and Top 20), and we plot the coefficient of the interaction (Recapitalized ${ }_{i t} \times$ Reputable $_{\mathrm{i}}$,). By extending the reputational criteria, some banks that are not truly reputable are artificially considered to be reputable. Figure IV.a shows that the impact of the negative effect of reputation after a bailout decreases and becomes 
statistically insignificant. This finding supports the reputational hypothesis, as only the most reputable underwriters are likely to suffer a loss in market share.

Secondly, we re-run our regressions computing the effect of bank bailouts for different sub-groups of banks (Top 1-5, Top 5-10, Top 10-15 and Top 15-20). In doing so, we are able to test whether the impact of a bank bailout differs according to differences in the ex-ante reputational capital of the sub-groups of banks. Figure IV.b plots the results. As we expected, the effect of the bailout (negative or positive) depends on the bailed-out bank's ex-ante reputational capital. Reputable banks suffer market shares losses, while less reputable banks experience gains

\section{ROBUSTNESS TESTS}

\subsection{Alternative market share measures}

A primary concern is ensuring that our results are not driven by how underwriters' market shares are computed when several underwriters place a bond. For robustness purposes, we compute as dependent variable market share full proceeds, which is calculated by assigning the total amount of the proceeds to each bank in case of syndicated bonds. Columns 1 and 2 in Table VIII show the results, which are consistent with the main findings reported in Table III. The coefficient of the interaction Recapitalized $_{i t} x$ Reputable $_{i}$,) remains significantly negative while the coefficient of Recapitalized $_{i t}$ is positive and statistically significant.

\subsection{Subsample: Active underwriters}

We are also concerned about the fact that some underwriters placed bonds in some but not all years of the research period. In order to ensure that our results are not driven by some banks placing bonds at particular moments due to specific isolated mandates, we re-estimate our model using a subsample of banks that placed bonds every year from 2006 
to 2013. The results are shown in Columns 3 and 4 of Table VIII and are similar to the baseline estimations.

\subsection{Placebo experiments}

Furthermore, as in related studies employing a DID methodology, we conduct some placebo experiments. Firstly, underwriters are randomly categorized as recapitalized or not recapitalized, and then the model is re-run with bootstrapped confidence intervals using 2,500 replications. We conduct a placebo experiment in which the timing of the bailout measure is faked. As in previous studies (Berger \& Roman, 2017; Calderon \& Schaeck, 2016; Puddu \& Wälchli, 2013), we assume that each of the bailout measures took place two years earlier than the real date, while still distinguishing between bailed-out and non-bailed-out banks. In both placebo experiments, all the main variables are statistically insignificant (Table VIII).

\subsection{Intensity of government support}

We test the robustness of our results to the intensity of government support by using alternative measures of Recapitalization. In particular, we replace the Recapitalization dummies with two continuous variables. Recapitalization Intensity is computed as the ratio of the total funds received by the underwriter to the underwriter's total assets, while Recapitalization Amount is the natural logarithm of the recapitalization amount plus one. As shown in Table VIII, after considering the intensity of the recapitalizations, the results regarding their effects remain very similar to the baseline findings.

\subsection{Self-selection}

To address the potential self-selection bias arising from being a bailed-out bank, we employ a two-stage Heckman selectivity model (Heckman, 1979). Here, we first estimate a probit model, regressing the Recapitalized dummy on all control variables from 
our main specification, as well as on certain determinants discussed in the literature on bank recapitalizations (Beccalli \& Frantz, 2016; Berger \& Bouwman, 2013; Gerhardt \& Vennet, 2017; Mariathasan \& Merrouche, 2012; Papanikolaou, 2018). From this probit estimation, we obtain the inverse Mills ratio, which is used as one of the regressors in the second-stage equation to produce consistent estimates of underwriters' market shares.

$$
\begin{aligned}
& \operatorname{Pr}(\text { Publicly Recapitalized Underwriter }=1 \mid \mathrm{X}=\mathrm{x})=\Lambda\left(\beta_{0}+\beta_{1} X_{\text {underwriter features }}+\right. \\
& \left.\beta_{2} X_{\text {country features }}+\sum_{h=1}^{h} \text { Year }_{h}+\sum_{k=1}^{k} \text { Underwriter nationality }_{k}+e_{i}\right)
\end{aligned}
$$

Consistent with prior studies on bank recapitalization, the likelihood of being recapitalized is regressed on specific features of underwriters-size, profitability, liquidity, capital adequacy, interbank lendings, age and being listed-and country features based on the underwriter's nationality, namely regulatory quality, stock market volatility, GDP growth and economic freedom. These variables are described in Table A.II Panel E. Table IX shows that large, less profitable and less liquid banks are more likely to be recapitalized. Additionally, these recapitalizations occur in countries with low GDP growth rates, volatile stock markets, high regulatory quality and a lower index of economic freedom. These results are in line with prior findings on public recapitalizations of banks (Beccalli \& Frantz, 2016; Li, 2013; Mariathasan \& Merrouche, 2012).

The second-stage results, also reported in Table IX, show that our results are not biased by sample selection. The inverse Mills ratio is not statistically significant.

\subsection{Instrumental Variable Analysis (IV)}

Due to the potential endogeneity of our Recapitalization variable, we conduct an instrumental variable (IV) analysis similar to those employed in earlier bank bailout studies (Berger, Makaew, \& Roman, 2018; Berger \& Roman, 2015, 2017; Calderon \& Schaeck, 2016; Dam \& Koetter, 2012; Duchin \& Sosyura, 2014). We consider three instruments that have been employed in prior papers dealing with endogeneity concerns in bank bailouts. Some earlier studies (Blau, Brough, \& Thomas, 2013; Dam \& Koetter, 
2012; Li, 2013; Lim, Hagendorff, \& Armitage, 2019) have found that banks' political and regulatory connections affect their probability of being bailed out. We thus use banks' political and regulatory connections (Pol_Reg connection) as an instrument. This variable is a dummy variable that equals one if the bank's chief executive or president has previously served as a politician, has been publicly appointed on a discretionary basis by the government or any public agency (i.e. Secretary of State, Director General) or has served in a financial regulatory/supervisory agency or central bank ${ }^{26}$. The second instrument is based on the importance of the regulatory architecture to the approval of a bailout. As in Calderon and Schaeck (2016), we use the prompt corrective power index built from the Bank Regulation and Supervision Survey in Barth, Caprio and Levine (2013). This index ranges from 0 to 6 and proxies whether there are predetermined levels of bank solvency deterioration that force automatic actions such as interventions. Third, we use a variable that captures the level of bank opacity. As argued by Flannery, Kwan and Nimalendran (2013), government interventions during the 2007-2009 crisis were predicated on spikes in information asymmetries because of bank opaqueness. Bank opacity is computed as the ratio of available for sale (AFS) securities to total securities.

Econometrically, because the potentially endogenous explanatory variable is binary, we employ a dummy endogenous variable model (Wooldridge, 2002). For the first stage, we use a probit model that regresses a discrete dummy for recapitalized banks on the instruments and all control variables of our baseline regression model. Subsequently, we use the predicted probability obtained from the first stage as an instrument for the second stage. The results are reported in Table X. Panel A presents the first-stage regression, and the second-stage results are shown in Panel B. The weak

\footnotetext{
${ }^{26}$ The information to build this variable was retrieved from a number of sources: CRP's Revolving Door database, RevolvingDoorWatch, Orbis BankFocus, LinkedIn, official public administration sources and the webpages of central banks and regulatory agencies
} 
instruments hypothesis can be rejected according to the first-stage F-tests and Kleibergen-Paap identification tests. All three instruments employed are statistically significant and have the expected sign. In the second-stage regression, we find that the main results hold.

\subsection{Alternative econometric specifications}

\subsubsection{Classical Difference-in-Difference}

While the main methodological approach employed in the paper is a generalized DID that addresses the fact that some banks were recapitalized repeatedly during the sample period, we also employ a simple DID approach. In particular, we use the Berger et al. $(2018,2019)$ and Berger and Roman $(2015,2017)$ specification as follows:

$$
\begin{aligned}
& \text { Mkt. Share }_{i t}=\alpha+\beta_{1} \text { Recapitalized }_{i}+\beta_{2} \text { Reputable }_{i}+\beta_{3} \text { Recapitalized }_{i} \text { x Reputable }_{i}
\end{aligned}
$$

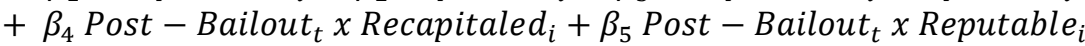

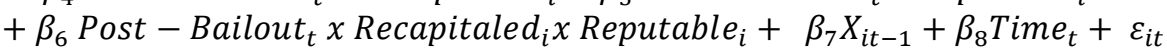

As we aim to examine the differences between bailed-out vs. non-bailed-out banks, reputable vs. non-reputable banks, and pre- vs. post-bailout periods (triple differences), in equation (5) we employ a specification with six betas ( $\beta 1$ - $\beta 6)$ plus time fixed effects to capture all eight scenarios $(2 \times 2 \times 2)$. The post-bailout dummy is not included, since it is implicitly captured by the time fixed effects. The dependent variable is the market share of underwriter $i$ in year $t$. Recapitalized $d_{i}$ is a dummy that takes the value 1 for the bailed-out banks (treated group). Post - Bailout $t_{t}$ is a dummy equal to 1 in 2009:Q1-2013:Q4 (as in Berger et al., 2018, 2019; Berger \& Roman, 2015, 2017, Duchin \& Sosyura, 2014) ${ }^{27}$. Consistent with the DID approach, those banks that received a first state capital injection after the treatment period ending in December 2010 are

\footnotetext{
${ }^{27}$ As in Berger, Makaew, \& Roman (2018) and Berger \& Roman (2015), the Post-Bailout dummy does not appear by itself on the right-hand side of the equation, because it would be collinear with the time fixed effects.
} 
excluded $^{28}$. The standard errors reported are robust to heteroscedasticity and clustered at the underwriter level.

The regression results, reported in Table XI, are qualitatively similar to those obtained in the main regressions.

\subsubsection{Matched differences-in-differences}

For robustness purposes, we also employ Gormley and Matsa's (2011, 2016) matched differences-in-differences estimator as an alternative approach to deal with multiple treatment events occurring at different times. This requires building a sample of banks for each year that a bailout measure is implemented. In this sample, bailed-out banks are considered as treated, while non-bailed-out banks are considered as control. For each such cohort sample, we analyze firm-year observations before and after the implementation of the bailout measure. We then pool the samples into one dataset, creating a variable that identifies the cohort to which each observation belongs, and we estimate the average effect. Table XII shows the results for the matched differences-indifferences estimator. The results are qualitatively similar to those obtained in the main regressions.

\section{CONCLUSIONS}

Underwriting has become a substantial revenue-generation source for banks. This growth of the underwriting business occurred at around the time of the financial crisis, when some of these banks had to be bailed out. In this paper, we explored the effects of these public capital infusions on the underwriting business. An investigation of the effects of state aid recapitalization measures is relevant, since according to the certification-

\footnotetext{
${ }^{28}$ Five banks were removed: Abanka Vipa, Banco BPI, Banco Grupo Cajatres, Millenium Investment Banking and Nova Ljubljanska Banka.
} 
reputational hypothesis, the information disclosed about beneficiaries may affect their future business.

Our research contributes to the extant literature on bank bailouts by indicating that bailout programs may have unintended effects not only on lending but also on banks' alternative businesses. Additionally, this paper contributes to the underwriting literature by exploring how certification-reputational concerns may affect underwriters' market shares after they have been publicly recapitalized. In doing so, along with the usual variables regarding banks' financial strength, we included a number of quantitative and qualitative drivers of underwriters' market shares. Furthermore, we did not focus on a specific bailout program, but on all the bailouts that may have affected the businesses of the underwriters competing in the European bond market.

Using a DID approach, we found that reputable underwriters suffered losses in underwriting market share after being state-aid-recapitalized, while state aid recapitalization increased the market shares of non-reputable underwriters. These results are found to be economically significant. The findings are consistent with the certification-reputational hypothesis for those banks with a large ex-ante reputational capital. Finally, we showed that the differential effect of ex-ante reputational capital is confirmed in a firm-bank matching analysis.

\section{References}

Abrahamson, M., Jenkinson, T., \& Jones, H. (2011). Why Don't U.S. Issuers Demand European Fees for IPOs? Journal of Finance, 66(6), 2055-2082.

Allen, F., Carletti, E., \& Marquez, R. (2011). Credit market competition and capital regulation. Review of Financial Studies, 24(4), 983-1018.

Andres, C., Betzer, A., \& Limbach, P. (2014). Underwriter reputation and the quality of certification: Evidence from high-yield bonds. Journal of Banking \& Finance, 40, 97-115.

Ang, J. S., \& Zhang, S. (2004). League table: a study of the competition to underwrite floating rate debt. Journal of International Financial Markets, Institutions and Money, 14(4), 329-349.

Autore, D. M., Kovacs, T., \& Sharma, V. (2009). Do analyst recommendations reflect shareholder rights ? Journal of Banking \& Finance, 33, 193-202.

Barth, J. R., Caprio, G., \& Levine, R. (2013). Bank Regulation and Supervision in 180 Countries from 1999 to 2011. National Bureau of Economic Research Working Paper 18733.

Barth, M. E., Zasznik, R., \& McNichols, M. F. (2001). Analyst Coverage and Intangible Assets. Journal of Accounting Research, 39(1), 1-34.

Bassett, W., Demiralp, S., \& Lloyd, N. (2017). Government support of banks and bank lending. Journal of Banking and Finance, 0, 1-16.

Bayazitova, D., \& Shivdasani, A. (2012). Assessing TARP. Review of Financial Studies, 25(2), 377-407. 
Beatty, P., \& Ritter, J. R. (1986). Investment and the Initial Public Offerings. Journal of Financial Economics, 15(June 1984), 213-232.

Beatty, R. P., Bunsis, H., \& Hand, J. R. M. (1998). The indirect economic penalties in SEC investigations of underwriters. Journal of Financial Economics, 50, 151-186.

Beccalli, E., \& Frantz, P. (2016). Why are some banks recapitalized and others taken over? Journal of International Financial Markets, Institutions and Money, 45(August), 79-95.

Bedendo, M., Cathcart, L., \& El-jahel, L. (2018). Reputational shocks and the information content of credit ratings. Journal of Financial Stability, 34, 44-60.

Berger, A. N., \& Bouwman, C. H. S. (2013). How does capital affect bank performance during financial crises? Journal of Financial Economics, 109(1), 146-176.

Berger, A. N., Bouwman, C. H. S., Kick, T., \& Schaeck, K. (2016). Bank liquidity creation following regulatory interventions and capital support. Journal of Financial Intermediation, 26, 115-141.

Berger, A. N., Makaew, T., \& Roman, R. (2018). Do Business Borrowers Benefit from Bank Bailout? The Effects of TARP on Loan Contract Terms. Financial Management, Forthcomin.

Berger, A. N., \& Roman, R. A. (2015). Did TARP Banks Get Competitive Advantages? Journal of Financial and Quantitative Analysis, 50(6), 1199-1236.

Berger, A. N., Roman, R. A., \& Sedunov, J. (2019). Did TARP reduce or increase systemic risk? The effects of government aid on financial system stability. Journal of Financial Intermediation, 1-22.

Berger, A., \& Roman, R. A. (2017). Did Saving Wall Street Really Save Main Street? The Real Effects of TARP on Local Economic Conditions. Journal of Financial and Quantitative Analysis, 1-41.

Bertrand, M., \& Mullainathan, S. (2003). Enjoying the Quiet Life ? Corporate Governance and Managerial Preferences. Journal of Political Economy, 111(5), 1043-1075.

Bertsatos, G., Sakellaris, P., \& Tsionas, M. G. (2017). Did the financial crisis affect the market valuation of large systemic U.S. banks? Journal of Financial Stability, 32, 115-123.

Bharath, S., Dahiya, S., Saunders, A., \& Srinivasan, A. (2007). So what do I get? The bank's view of lending relationships. Journal of Financial Economics, 85(2), 368-419.

Black, L. K., \& Hazelwood, L. N. (2013). The effect of TARP on bank risk-taking. Journal of Financial Stability, 9(4), 790-803.

Blau, B. M., Brough, T. J., \& Thomas, D. W. (2013). Corporate lobbying, political connections, and the bailout of banks. Journal of Banking and Finance, 37(8), 3007-3017.

Booth, J. R., \& Smith, R. L. (1986). Capital raising, underwriting and the certification hypothesis. Journal of Financial Economics, 15, 261-281.

Burch, T. R., Nanda, V., \& Warther, V. (2005). Does it pay to be loyal? An empirical analysis of underwriting relationships and fees. Journal of Financial Economics, 77(3), 673-699.

Calderon, C., \& Schaeck, K. (2016). The Effects of Government Interventions in the Financial Sector on Banking Competition and the Evolution of Zombie Banks. Journal of Financial and Quantitative Analysis, 51(4), 13911436.

Carbó-Valverde, S., Cuadros-Solas, P. J., \& Rodríguez-Fernández, F. (2017). Do banks and industrial companies have equal access to reputable underwriters in debt markets? Journal of Corporate Finance, 45, 176-202.

Carbó-Valverde, S., Maqui-López, E., \& Rodriguez-Fernandez, F. (2013). Trust in Banks: Evidence from the Spanish Financial Crisis.

Carter, R. B., Dark, F. H., \& Singh, A. K. (1998). Underwriter Reputation , Initial Returns , and the Long-Run Performance of IPO Stocks. The Journal of Finance, 53(1), 285-311.

Carter, R., \& Manaster, S. (1990). Initial Public Offerings and Underwriter Reputation. The Journal of Finance, 45(4), $1045-1067$.

Carvalho, D., Ferreira, M. A., \& Matos, P. (2015). Lending Relationships and the Effect of Bank Distress : Evidence from the 2007 - 2009 Financial Crisis. Journal of Financial and Quantitative Analysis, 50(6), 1165-1197.

Chemmanur, T. J., \& Fulghieri, P. (1994). Investment Bank Reputation , Information Production, and Financial Intermediation. The Journal of Finance, 49(1), 57-79.

Chen, C., Shi, H., \& Xu, H. (2014). The IPO underwriting market share in China: Do ownership and quality matter? Journal of Banking \& Finance, 46, 177-189.

Chen, Q., \& Vashishtha, R. (2017). The effects of bank mergers on corporate information disclosure. Journal of Accounting and Economics, 64(1), 56-77.

Corbett, J., \& Mitchell, J. (2000). Banking Crises and Bank Rescues: The Effect of Reputation. Journal of Money, Credit and Banking, 32(3), 474-512.

Cornett, M. M., McNutt, J. J., Strahan, P. E., \& Tehranian, H. (2011). Liquidity risk management and credit supply in the financial crisis. Journal of Financial Economics, 101(2), 297-312.

Corwin, S., \& Schultz, P. (2005). The Role of IPO Underwriting Syndicates : Pricing, Information Production, and Underwriter Competition. Journal of Finance, 60(February), 443-486.

Corwin, S., \& Stegemoller, M. (2014). The Changing Nature of Investment Banking Relationships.

Croci, E., Degl'Innocenti, M., \& Zhou, S. (2019). Supply Chain Relationships and Bank Lending. Working Paper.

Dai, N., Jo, H., \& Schatzberg, J. D. (2010). The Quality and Price of Investment Banks' Service: Evidence from the PIPE Market. Financial Management, 39(2), 585-612.

Dam, L., \& Koetter, M. (2012). Bank bailouts and moral hazard: Evidence from Germany. Review of Financial Studies, 25(8), 2343-2380.

Dong, M., Michel, J.-S., \& Pandes, J. A. (2011). Underwriter Quality and Long-Run. Financial Management, 219251. 
Drucker, S., \& Puri, M. (2005). On the Benefits of Concurrent Lending. The Journal of Finance, LX(6), 2763-2799.

Duarte-Silva, T. (2010). The market for certification by external parties: Evidence from underwriting and banking relationships. Journal of Financial Economics, 98(3), 568-582.

Duchin, R., \& Sosyura, D. (2014). Safer ratios, riskier portfolios: Banks' response to government aid. Journal of Financial Economics, 113(1), 1-28.

Dunbar, C. G. (2000). Factors affecting investment bank initial public offering market share. Journal of Financial Economics, 55(2000), 3-41.

Dyck, A., Morse, A., \& Zingales, L. (2010). Who blows the whistle on corporate fraud? Journal of Finance, 65(6), 2213-2253.

Fang, L. H. (2005). Investment Bank Reputation and the Price and Quality of Underwriting Services. The Journal of Finance, 60(6), 2729-2761.

Fang, L. H., \& Yasuda, A. (2014). Are Stars ' Opinions Worth More? The Relation Between Analyst Reputation and Recommendation Values. Journal of Financial Services Research, 46, 235-269.

Fang, L., \& Yasuda, A. (2009). The effectiveness of reputation as a disciplinary mechanism in sell-side research. Review of Financial Studies, 22(9), 3735-3777.

Fang, Y., Hasan, I., \& Marton, K. (2014). Institutional development and bank stability: Evidence from transition countries. Journal of Banking and Finance, 39(1), 160-176.

Fernando, C. S., Gatchev, V. a., May, A. D., \& Megginson, W. L. (2015). Prestige without purpose? Reputation, differentiation, and pricing in U.S. equity underwriting. Journal of Corporate Finance, 32, 41-63.

Fernando, C. S., Gatchev, V. A., \& Spindt, P. A. (2005). Wanna Dance? How Firms and Underwriters Choose Each Other. The Journal of Finance, LX(5), 2437-2469.

Fernando, C. S., May, A. D., \& Megginson, W. L. (2012). The Value of Investment Banking Relationships : Evidence from the Collapse of Lehman Brothers. The Journal of Finance, LXVII(1), 235-270.

Fiordelisi, F., Soana, M. G., \& Schwizer, P. (2013). The determinants of reputational risk in the banking sector. Journal of Banking and Finance, 37(5), 1359-1371.

Fiordelisi, F., Soana, M. G., \& Schwizer, P. (2014). Reputational losses and operational risk in banking. European Journal of Finance, 20(2), 105-124.

Flannery, M. J., Kwan, S. H., \& Nimalendran, M. (2013). The 2007-2009 financial crisis and bank opaqueness. Journal of Financial Intermediation, 22(1), 55-84.

Francis, B. B., Hasan, I., John, K., \& Waisman, M. (2010). The effect of state antitakeover laws on the firm's bondholders. Journal of Financial Economics, 96(1), 127-154.

Franck, A., \& Kerl, A. (2013). Analyst forecasts and European mutual fund trading. Journal of Banking and Finance, 37(8), 2677-2692.

Gande, A., Puri, M., Saunders, A., \& Walter, I. (1997). Bank Underwriting of Debt Securities: Modern Evidence. The Review of Financial Studies, 10(4), 1175-1202.

Gerhardt, M., \& Vennet, R. Vander. (2017). Bank bailouts in Europe and bank performance. Finance Research Letters, $22,74-80$.

Gleason, C. A., \& Lee, C. M. C. (2003). Aanalyst Forecast Revisions and Market Price Discovery. The Accounting Review, 78(1), 193-225.

Gopalan, R., Nanda, V., \& Yerramilli, V. (2011). Does Poor Performance Damage the Reputation of Financial Intermediaries? Evidence from the Loan Syndication Market. Journal of Finance, 66(6), 2083-2120.

Gormley, T. A., \& Matsa, D. A. (2011). Growing out of trouble? corporate responses to liability risk. Review of Financial Studies, 24(8), 2781-2821.

Gormley, T. A., \& Matsa, D. A. (2016). Playing it safe? Managerial preferences, risk, and agency conflicts. Journal of Financial Economics, 122(3), 431-455.

Hakenes, H., \& Schnabel, I. (2010). Banks without parachutes: Competitive effects of government bail-out policies. Journal of Financial Stability, 6(3), 156-168.

Hanley, K. W., \& Hoberg, G. (2012). Litigation risk , strategic disclosure and the underpricing of initial public offerings. Journal of Financial Economics, 103(2), 235-254.

Hasan, I., Jackowicz, K., Kowalewski, O., \& Kozłowski, Ł. (2013). Market discipline during crisis: Evidence from bank depositors in transition countries. Journal of Banking and Finance, 37(12), 5436-5451.

Haselmann, R., Pistor, K., \& Vig, V. (2010). How law affects lending. Review of Financial Studies, 23(2), 549-580.

Heckman, J. J. (1979). Sample Selection Bias as a Specification Error. Econometrica: Journal of the Econometric Society, 47(1), 153-161.

Hellmann, T., Lindsey, L., \& Puri, M. (2008). Building Relationships Early: Banks in Venture Capital. Review of Financial Studies, 21(2), 513-541.

Humphery-Jenner, M., Karpavicius, S., \& Suchard, J. A. (2018). Underwriter relationships and shelf offerings. Journal of Corporate Finance, 49, 283-307.

Huyghebaert, N., \& Xu, W. (2015). What determines the market share of investment banks in Chinese domestic IPOs? China Economic Review, 34, 0-47.

Jackson, A. R. (2005). Trade Generation, Reputation, and Sell-Side Analysts. The Journal of Finance, LX(2), 673-717.

Jiraporn, P., Chintrakarn, P., \& Kim, Y. S. (2012). Analyst following, staggered boards, and managerial entrenchment. Journal of Banking \& Finance, 36, 3091-3100.

Khwaja, A., \& Mian, A. (2008). Tracing the Impact of Bank Liquidity Shocks. American Economic Review, 98(4), $1413-1442$.

King, M. R. (2019). Time to buy or just buying time? Lessons from October 2008 for the cross-border bailout of banks. Journal of Financial Stability, 41(October 2008), 55-72. 
Knell, M., \& Stix, H. (2009). Trust in Banks? Evidence from normal times and from times of crises.

Koetter, Michael; Noth, F. (2016). Did TARP distort competition among sound banks? Economic Enquiry, 54(2).

Krigman, L., Shaw, W. H., \& Womack, K. L. (2001). Why do firms switch underwriters? Journal of Financial Economics, 60, 245-284.

Kuhnen, C. M. (2009). Business Networks, Corporate Governance, and Contracting in the Mutual Fund Industry. Journal of Finance, LXIV(5), 2185-2220.

Li, L. (2013). TARP funds distribution and bank loan supply. Journal of Banking and Finance, 37(12), 4777-4792.

Lim, I., Hagendorff, J., \& Armitage, S. (2019). Is the fox guarding the henhouse? Bankers in the Federal Reserve, bank leverage and risk-shifting. Journal of Corporate Finance, 58(March), 478-504.

Liu, W., Kolari, J. W., Kyle Tippens, T., \& Fraser, D. R. (2013). Did capital infusions enhance bank recovery from the great recession? Journal of Banking and Finance, 37(12), 5048-5061.

Liu, X., \& Ritter, J. R. (2011). Local underwriter oligopolies and IPO underpricing. Journal of Financial Economics, $102(3), 579-601$.

Livingston, M., \& Miller, R. E. (2000). Investment Bank Reputation and the Underwriting of Nonconvertible Debt. Financial Management, 29(2), 21-34.

Ljungqvist, A., Marston, F., \& Wilhelm, W. J. (2006). Competing for Securities Underwriting Mandates : Banking Relationships and Analyst Recommendations. The Journal of Finance, LXI(1), 301-340.

López-Espinosa, G., Moreno, A., Rubia, A., \& Valderrama, L. (2013). Drivers of Fiscal Outlays in the Public Recapitalization of Banks.

Mariathasan, M., \& Merrouche, O. (2012). Recapitalization, credit and liquidity. Economic Policy, 27(72), 603-646.

McCahery, J., \& Schwienbacher, A. (2010). Bank reputation in the private debt market. Journal of Corporate Finance, 16(4), 498-515.

Megginson, W. L., \& Weiss, K. A. (1991). Venture Capitalist Certification in Initial Public Offerings. The Journal of Finance, 46(3), 879-903.

Migliorati, K., \& Vismara, S. (2014). Ranking Underwriters of European IPOs. European Financial Management, 20(5), 891-925.

Montgomery, H., \& Takahashi, Y. (2014). The economic consequences of the TARP: The effectiveness of bank recapitalization policies in the U.S. Japan and the World Economy, 32, 49-64.

Mosch, R., \& Prast, H. (2008). Confidence and trust: empirical investigations for the Netherlands and the financial sector. Occasional Studies, 6(2).

Nakashima, K. (2016). An econometric evaluation of bank recapitalization programs with bank- and loan-level data. Journal of Banking and Finance, 63, 1-24.

Narayanan, R. P., Rangan, K. P., \& Rangan, N. K. (2006). The Effect of Private-Debt-Underwriting Reputation on Bank Public-Debt Underwriting. Review of Financial Studies, 20(3), 597-618.

Neupane, S., \& Thapa, C. (2013). Underwriter reputation and the underwriter-investor relationship in IPO markets. Journal of International Financial Markets, Institutions and Money, 24, 105-126.

Papanikolaou, N. I. (2018). To be bailed out or to be left to fail? A dynamic competing risks hazard analysis. Journal of Financial Stability, 34, 61-85.

Philippon, T., \& Skreta, V. (2012). Optimal Interventions in Markets with Adverse Selection. American Economic Review, 102(1), 1-28.

Poczter, S. (2016). The long-term effects of bank recapitalization : Evidence from Indonesia. Journal of Financial Intermediation, 25, 131-153.

Rau, P. R. (2000). Investment bank market share, contingent fee payments, and the performance of acquiring firms. Journal of Financial Economics, 56, 293-324.

Sapienza, P., \& Zingales, L. (2012). A Trust Crisis. International Review of Finance, 12(2), 123-131.

Schenone, C. (2004). The effect of banking relationships on the firm's IPO underpricing. The Journal of Finance, 59(6), 2903-2958.

Schnabl, P. (2012). The International Transmission of Bank Liquidity Shocks: Evidence from an Emerging Market. Journal of Finance, 67(3), 897-932.

Smith, C. W. (1992). Economics and Ethics: The Case of Salomon Brothers. Journal of Applied Corporate Finance, $5,23-28$.

Sufi, A. (2007). Information Asymmetry and Financing Arrangements : Evidence from Syndicated Loans. The Journal of Finance, LXII(2), 629-668.

van der Cruijsen, C., \& Diepstraten, M. (2017). Banking Products: You Can Take Them with You, So Why Don't You? Journal of Financial Services Research, 52(1-2), 123-154.

Veronesi, P., \& Zingales, L. (2010). Paulson's gift. Journal of Financial Economics, 97(3), 339-368.

Vismara, S., Paleari, S., \& Ritter, J. R. (2012). Europe's second markets for small companies. European Financial Management, 18(3), 352-388.

Wooldridge, J. M. (2002). Econometric Analysis of Cross Section and Panel Data. (M. Cambridge, Ed.), booksgooglecom (Vol. 58). MIT Press.

Yasuda, A. (2005). Do Bank Relationships Affect the Firm 's Underwriter Choice in the Corporate-Bond Underwriting Market? The Journal of Finance, LX(3).

Yasuda, A. (2007). Bank relationships and underwriter competition: Evidence from Japan. Journal of Financial Economics, 86(2), 369-404.

Zanzalari, D. (2015). The Effect of Nontraditional Banking on Entry into TARP and Bank Failure. 
FIGURE I

EVOLUTION OF THE UNDERWRITING INDUSTRY IN THE EUROPEAN BOND MARKETS

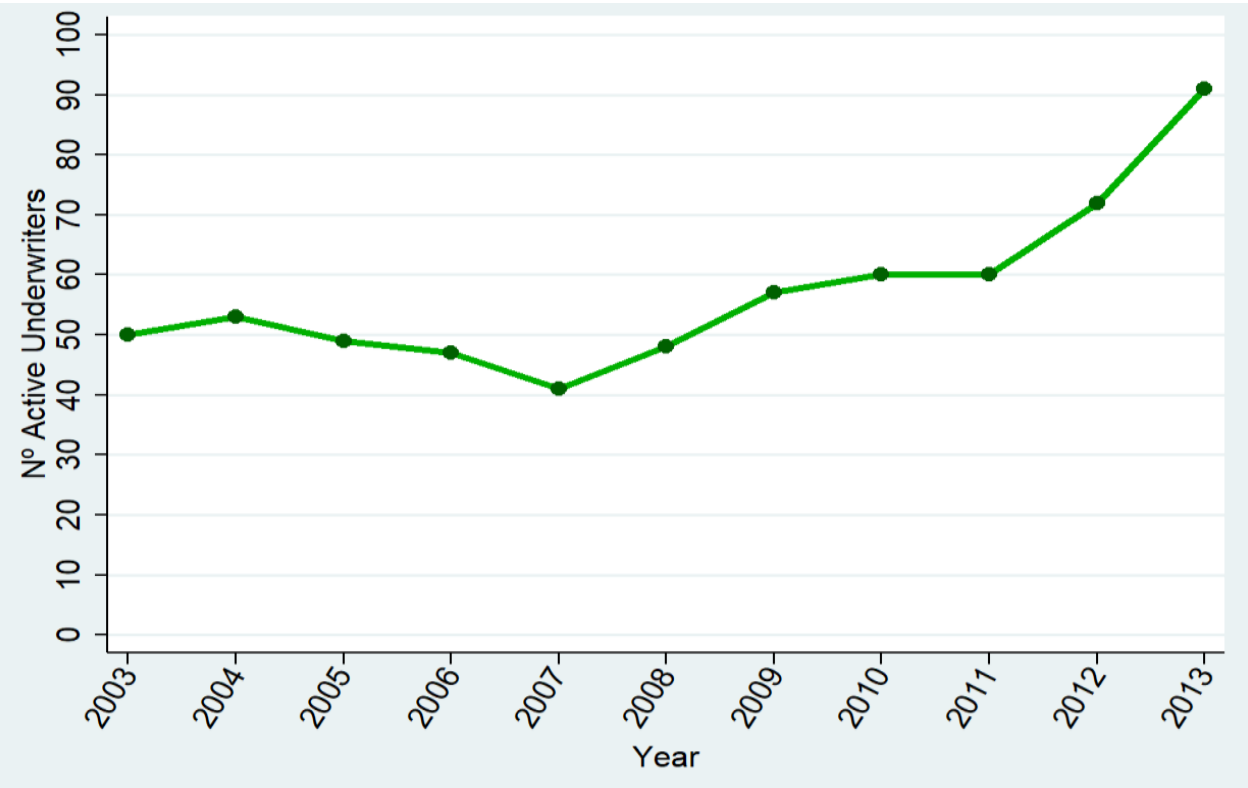

FIGURE II

EVOLUTION OF UNDERWRITERS' MARKET SHARES FOR RECAPITALIZED BANKS BY REPUTATION (2008 - 2013)
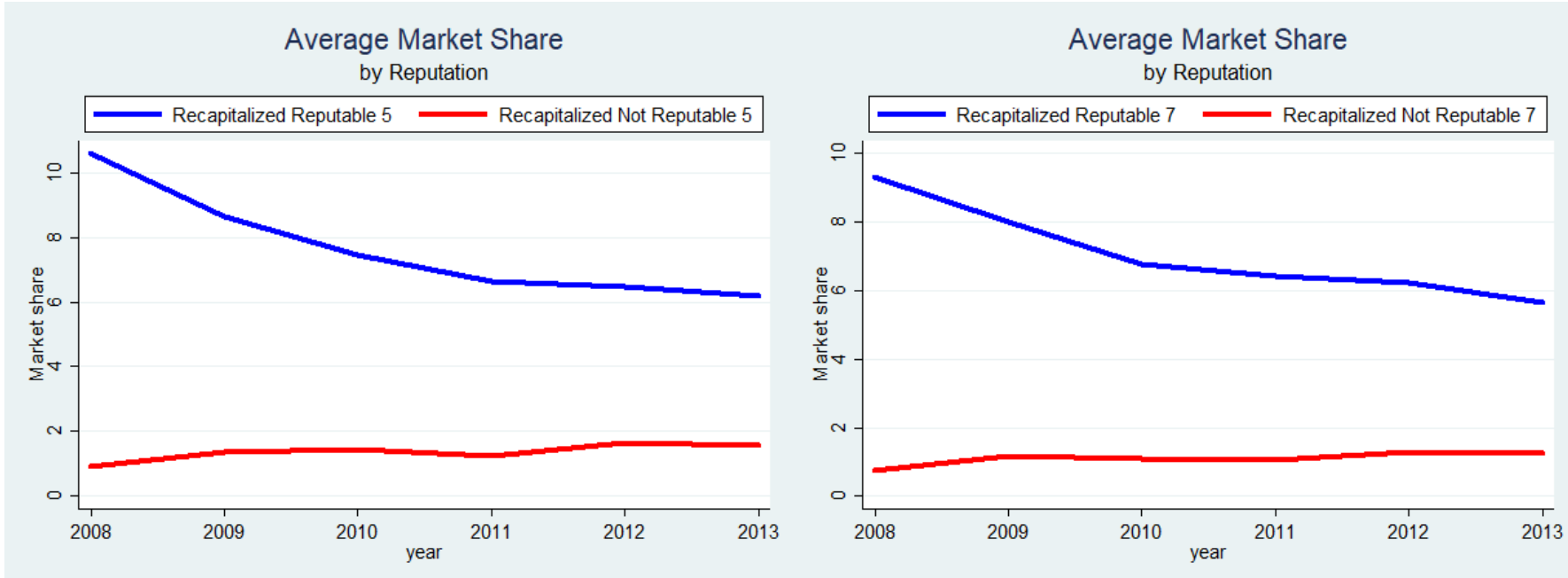
TABLE I

SUMMARY STATISTICS OF THE UNDERWRITING EUROPEAN CORPORATE BOND MARKET

\begin{tabular}{|c|c|c|c|c|c|c|c|c|c|}
\hline \multirow{6}{*}{ Ranking } & & 2006 & 2007 & 2008 & 2009 & 2010 & 2011 & 2012 & 2013 \\
\hline & 1 & $\begin{array}{c}\text { Deutsche } \\
\text { Bank }\end{array}$ & $\begin{array}{c}\text { Deutsche } \\
\text { Bank }\end{array}$ & RBS & $\begin{array}{c}\text { Deutsche } \\
\text { Bank }\end{array}$ & $\begin{array}{c}\text { Deutsche } \\
\text { Bank }\end{array}$ & $\begin{array}{c}\text { Deutsche } \\
\text { Bank }\end{array}$ & HSBC & $\begin{array}{c}\text { Deutsche } \\
\text { Bank }\end{array}$ \\
\hline & 2 & JPMorgan & Citi & $\begin{array}{c}\text { Deutsche } \\
\text { Bank }\end{array}$ & RBS & Barclays & RBS & Barclays & HSBC \\
\hline & 3 & Barclays & HSBC & $\begin{array}{c}\text { BNP } \\
\text { Paribas }\end{array}$ & $\begin{array}{c}\text { BNP } \\
\text { Paribas }\end{array}$ & $\begin{array}{c}\text { BNP } \\
\text { Paribas }\end{array}$ & Citi & RBS & $\begin{array}{l}\text { BNP } \\
\text { Paribas }\end{array}$ \\
\hline & 4 & $\begin{array}{l}\text { Morgan } \\
\text { Stanley }\end{array}$ & JPMorgan & HSBC & $\begin{array}{c}\text { Societe } \\
\text { Generale }\end{array}$ & RBS & $\begin{array}{c}\text { BNP } \\
\text { Paribas } \\
\end{array}$ & $\begin{array}{c}\text { Deutsche } \\
\text { Bank }\end{array}$ & JPMorgan \\
\hline & 5 & Citi & $\begin{array}{l}\text { BNP } \\
\text { Paribas }\end{array}$ & JPMorgan & HSBC & HSBC & JPMorgan & $\begin{array}{c}\text { BNP } \\
\text { Paribas }\end{array}$ & Barclays \\
\hline Active Underwriters & & 38 & 41 & 48 & 58 & 62 & 63 & 74 & 94 \\
\hline Total $n^{\circ}$ of bonds & & 119 & 113 & 131 & 242 & 235 & 235 & 375 & 397 \\
\hline Total proceeds raised (mill.\$ & & 81181.55 & 88297.53 & 88195.37 & 238553.97 & 144511.97 & 149058.70 & 242770.41 & 236520.71 \\
\hline Average UW mkt. share & & 2.69 & 2.50 & 2.17 & 1.81 & 1.69 & 1.67 & 1.41 & 1.10 \\
\hline Median UW mkt. share & & 0.64 & 1.67 & 0.53 & 0.35 & 0.60 & 0.54 & 0.24 & 0.19 \\
\hline HHI (UW) & & 0.0684 & 0.0599 & 0.0762 & 0.0601 & 0.0500 & 0.0486 & 0.0443 & 0.0417 \\
\hline Average Lending mkt. share & & 1.74 & 1.78 & 1.52 & 1.32 & 1.23 & 1.30 & 1.09 & 0.87 \\
\hline Median Lending mkt. share & & 1.30 & 1.19 & 1.07 & 0.63 & 0.68 & 0.71 & 0.55 & 0.29 \\
\hline
\end{tabular}

TABLE II

DESCRIPTIVE STATISTICS OF THE MAIN VARIABLES

\begin{tabular}{|c|c|c|c|c|c|c|c|}
\hline \multicolumn{6}{|c|}{ 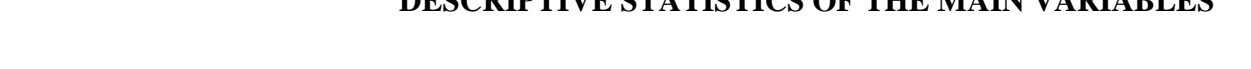 } & $\begin{array}{c}\text { Non } \\
\text { Bailed-out } \\
\end{array}$ & Bailed-out \\
\hline & mean & p50 & p25 & p75 & sd & \multicolumn{2}{|c|}{ mean } \\
\hline Market Share & 0.88 & 0.01 & 0.00 & 0.45 & 1.99 & 0.52 & 1.94 \\
\hline \multicolumn{8}{|c|}{ Determinants of Uws market share } \\
\hline Abnormal Bond Spreads & 0.00 & 0.00 & 0.00 & 0.00 & 0.09 & 0.00 & 0.01 \\
\hline Abnormal Fees & 27.67 & 0.00 & 0.00 & 28.12 & 91.60 & 24.80 & 35.94 \\
\hline HHI Industrial Specialization & 3239.71 & 1383.80 & 0.00 & 5381.45 & 3796.44 & 3379.00 & 2837.60 \\
\hline $\mathrm{N}^{\mathrm{o}}$ Total Star Analyst (\%) & 0.01 & 0.00 & 0.00 & 0.00 & 0.03 & 0.00 & 0.02 \\
\hline UW Lender & 0.17 & 0.00 & 0.00 & 0.00 & 0.38 & 0.11 & 0.36 \\
\hline Lending Mktshare & 0.74 & 0.17 & 0.00 & 0.99 & 1.22 & 0.48 & 1.48 \\
\hline Private Placement & 0.03 & 0.00 & 0.00 & 0.00 & 0.12 & 0.03 & 0.04 \\
\hline Multiple Uws & 0.56 & 0.89 & 0.00 & 1.00 & 0.47 & 0.49 & 0.75 \\
\hline \multicolumn{8}{|c|}{ Determinants of underwriters' financial health } \\
\hline UW size & 12.09 & 12.80 & 11.27 & 13.66 & 2.27 & 11.64 & 13.25 \\
\hline ROE & 5.60 & 9.49 & 4.04 & 14.99 & 39.94 & 9.80 & -5.12 \\
\hline Liquidity & 57.09 & 36.50 & 21.21 & 61.78 & 81.47 & 59.37 & 51.50 \\
\hline Capital Adequacy & 14.72 & 6.18 & 4.41 & 8.66 & 69.29 & 18.25 & 5.68 \\
\hline Operation Efficiency & 66.73 & 60.89 & 51.25 & 71.06 & 38.48 & 64.49 & 72.58 \\
\hline Age & 1.54 & 2.05 & 0.00 & 2.96 & 1.45 & 1.33 & 2.14 \\
\hline \multirow[t]{2}{*}{ Listed } & 0.74 & 1.00 & 0.00 & 1.00 & 0.44 & 0.74 & 0.75 \\
\hline & & & & & $\mathrm{n}=$ & 591 & 203 \\
\hline
\end{tabular}


TABLE III

DIFFERENCE-IN-DIFFERENCES REGRESSIONS ON UNDERWRITER MARKET SHARES

This table presents the coefficients for the difference-in-differences estimations for underwriter market shares for fixed corporate bonds in Europe from 2006-2013. The dependent variable is underwriter market share computed on a proceeds base, in which proceeds of syndicated bonds are split among all the underwriters. Column I and II presents the results for Equation 1. Column III and IV present the results for Equation 2. All the explanatory variables are described in the Appendix Table A.II. A constant term (not reported) is included in all regressions. Z-statistics are based on underwriter clustered standard errors. *, **, *** Coefficients are statistically significant different than zero at least at $10 \%, 5 \%$ and $1 \%$ levels.

\begin{tabular}{|c|c|c|c|c|}
\hline \multirow{2}{*}{$\begin{array}{l}\text { Dependent Variable: } \\
\text { Mkt. share Proceeds } \\
\text { Apportioned } \\
\text { Recapitalized }_{\text {it }}\end{array}$} & \multicolumn{2}{|c|}{ Equation 1} & \multicolumn{2}{|c|}{$\begin{array}{c}\text { Equation } 2 \\
\text { Reputable: Top } 5\end{array}$} \\
\hline & $\begin{array}{c}0.00407 \\
(0.116)\end{array}$ & $\begin{array}{l}0.0734 \\
(0.119)\end{array}$ & $\begin{array}{c}0.107 * \\
(0.0640)\end{array}$ & $\begin{array}{c}0.199 * * \\
(0.121)\end{array}$ \\
\hline Recapitalized $_{\text {it }}$ x Reputable ${ }_{i}$ & & & $\begin{array}{c}-1.324 * * \\
(0.385)\end{array}$ & $\begin{array}{c}-1.204 * * * \\
(0.356)\end{array}$ \\
\hline Abnormal Bond Spreads & & $\begin{array}{c}0.000189 \\
(0.000373)\end{array}$ & & $\begin{array}{c}0.000250 \\
(0.000365)\end{array}$ \\
\hline Abnormal Fees & & $\begin{array}{c}0.179 \\
(0.373)\end{array}$ & & $\begin{array}{l}0.0172 \\
(0.366)\end{array}$ \\
\hline HHI Industry Specialization & & $\begin{array}{c}-4.07 \mathrm{e}-05 * * * \\
(1.29 \mathrm{e}-05)\end{array}$ & & $\begin{array}{l}6.41 \mathrm{e}-06 \\
(1.60 \mathrm{e}-05)\end{array}$ \\
\hline Number Total Star Analyst i,t-1 & & $\begin{array}{c}0.0737 * * * \\
(0.0245)\end{array}$ & & $\begin{array}{c}0.0542 * * \\
(0.0244)\end{array}$ \\
\hline UW Lender $_{i, t}$ & & $\begin{array}{c}0.498 * * * \\
(0.112)\end{array}$ & & $\begin{array}{c}0.396 * * * \\
(0.111)\end{array}$ \\
\hline Lending Mktshare $_{i, t}$ & & $\begin{array}{l}0.00585 \\
(0.0122)\end{array}$ & & $\begin{array}{l}0.00529 \\
(0.0119)\end{array}$ \\
\hline Private Placement & & $\begin{array}{c}0.230 \\
(0.328)\end{array}$ & & $\begin{array}{l}-0.127 \\
(0.328)\end{array}$ \\
\hline Multiple Uws & & $\begin{array}{c}0.396 * * * \\
(0.131)\end{array}$ & & $\begin{array}{c}-0.0232 \\
(0.153)\end{array}$ \\
\hline UW size & & $\begin{array}{c}0.481 * * * \\
(0.149)\end{array}$ & & $\begin{array}{c}0.452 * * * \\
(0.146)\end{array}$ \\
\hline ROE & & $\begin{array}{l}-0.000530 \\
(0.000957)\end{array}$ & & $\begin{array}{l}-0.000378 \\
(0.000936)\end{array}$ \\
\hline Liquidity & & $\begin{array}{l}-0.000827 \\
(0.000754)\end{array}$ & & $\begin{array}{c}-0.00105 \\
(0.000739)\end{array}$ \\
\hline Capital Adequacy & & $\begin{array}{c}0.0239 \\
(0.0163)\end{array}$ & & $\begin{array}{l}0.0276^{*} \\
(0.0159)\end{array}$ \\
\hline Operation Efficiency & & $\begin{array}{c}0.000106 \\
(0.000999)\end{array}$ & & $\begin{array}{c}0.000215 \\
(0.000977)\end{array}$ \\
\hline Age & & $\begin{array}{l}1.98 \mathrm{e}-05 \\
(0.0684)\end{array}$ & & $\begin{array}{l}0.00990 \\
(0.0670)\end{array}$ \\
\hline Listed & & $\begin{array}{c}-0.00491 \\
(0.316)\end{array}$ & & $\begin{array}{l}-0.0146 \\
(0.309)\end{array}$ \\
\hline Time Fixed Effects & Yes & Yes & Yes & Yes \\
\hline UW Fixed Effects & Yes & Yes & Yes & Yes \\
\hline $\begin{array}{l}\text { F-test } \\
\text { Observations } \\
\text { R-squared }\end{array}$ & $\begin{array}{c}0.000 \\
833 \\
0.090\end{array}$ & $\begin{array}{c}0.000 \\
833 \\
0.394\end{array}$ & $\begin{array}{c}0.000 \\
833 \\
0.128\end{array}$ & $\begin{array}{c}0.000 \\
833 \\
0.407\end{array}$ \\
\hline
\end{tabular}


TABLE IV

FIRM-BANK MATCHING: WINNING A MANDATE

This table presents the coefficients and the z-statistics for the conditional fixed effects logit regressions for the determinants of being chosen as underwriter in a given deal. All variables are defined in the Appendix. Z-statistics are based on bond clustered standard errors. A constant term (not reported) is included in all regressions. $*, * *, * * *$ Coefficients are statistically significant different than zero at least at $10 \%, 5 \%$ and $1 \%$.

\begin{tabular}{|c|c|c|c|c|}
\hline & \multirow[t]{2}{*}{ VARIABLES } & \multicolumn{3}{|c|}{ Dep. Var: UW Chosen ( $0 \mid 1)$} \\
\hline & & $\begin{array}{l}\text { Firm-Bank Matching: } \\
\text { Winning Mandate }\end{array}$ & $\begin{array}{l}\text { Subsample: Firms issuing } \\
\text { in the pre-crisis \& crisis }\end{array}$ & $\begin{array}{l}\text { Subsample: Firms without } \\
\text { prior lending relationships }\end{array}$ \\
\hline & Recapitalizedit $_{\text {in }}$ & $0.139 * *$ & $0.165 * *$ & $0.236^{* * *}$ \\
\hline & & $(0.0569)$ & $(0.0714)$ & $(0.0800)$ \\
\hline & Reputable $_{i}$ & $0.348 * * *$ & $0.461 * * *$ & $0.686 * * *$ \\
\hline & & $(0.0767)$ & $(0.0929)$ & $(0.116)$ \\
\hline & Recapitalized $_{i t} \times$ Reputable $_{i}$ & $-0.175 * *$ & $-0.207 * *$ & $-0.339 * *$ \\
\hline & & $(0.0874)$ & $(0.976)$ & $(0.141)$ \\
\hline \multirow{14}{*}{ 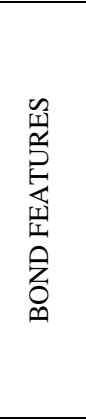 } & Bond size & $0.109^{* *}$ & $0.122 * * *$ & $0.129 * *$ \\
\hline & & $(0.0428)$ & $(0.0318)$ & $(0.0613)$ \\
\hline & Maturity & 0.0264 & 0.0223 & 0.00402 \\
\hline & & $(0.0278)$ & $(0.0165)$ & $(0.0804)$ \\
\hline & Callability & 0.0348 & 0.0266 & 0.0940 \\
\hline & & $(0.0660)$ & $(0.106)$ & $(0.109)$ \\
\hline & Domestic Placement & $-0.164^{*}$ & -0.117 & -0.360 \\
\hline & & $(0.0894)$ & $(0.0898)$ & $(0.484)$ \\
\hline & Investment Grade & 0.176 & 0.0821 & -0.0108 \\
\hline & & $(0.273)$ & $(0.307)$ & $(0.223)$ \\
\hline & Collateral & 0.0463 & $0.180^{*}$ & $0.175^{*}$ \\
\hline & & $(0.215)$ & $(0.109)$ & $(0.113)$ \\
\hline & Syndicate Size & $0.278 * * *$ & $0.275 * * *$ & $0.248 * * *$ \\
\hline & & $(0.0400)$ & $(0.0579)$ & $(0.0271)$ \\
\hline \multirow{8}{*}{ 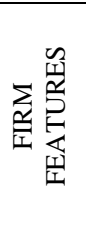 } & Firm size & 0.120 & 0.0536 & 0.177 \\
\hline & & (5.666) & $(5.403)$ & $(0.595)$ \\
\hline & Firm Leverage & 0.0280 & 0.334 & 0.0513 \\
\hline & & (3.264) & $(4.674)$ & $(0.963)$ \\
\hline & Firm ROA & 0.00105 & 0.00408 & -0.0122 \\
\hline & & $(0.0145)$ & $(0.0345)$ & $(0.0182)$ \\
\hline & First time issuer & $0.111^{*}$ & 0.0128 & 0.194 \\
\hline & & $(0.0675)$ & $(0.164)$ & $(0.205)$ \\
\hline \multirow{30}{*}{ 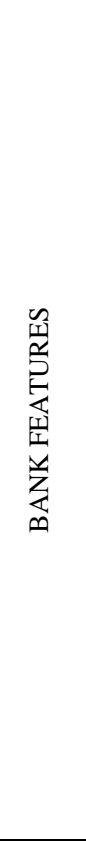 } & Abnormal Bond Spreads & $-0.00186^{* * *}$ & $-0.00204 * *$ & $-0.00356^{* * *}$ \\
\hline & & $(0.000689)$ & (0.000802) & $(0.00111)$ \\
\hline & Abnormal Fees & -0.101 & -0.486 & $0.839 *$ \\
\hline & & $(0.414)$ & $(0.616)$ & $(0.433)$ \\
\hline & HHI Industry Specialization & $-0.000158 * * *$ & $-0.000115 * * *$ & $-9.89 \mathrm{e}-05 * * *$ \\
\hline & & $(3.03 \mathrm{e}-05)$ & $(4.00 \mathrm{e}-05)$ & $(2.23 \mathrm{e}-05)$ \\
\hline & Number Total Star Analyst (\%) i,t-1 & 0.708 & -0.225 & 0.0897 \\
\hline & & $(0.895)$ & $(1.263)$ & $(0.578)$ \\
\hline & UW Lender $i, t$ & $0.287 * * *$ & $0.276^{* * *}$ & $0.232 * *$ \\
\hline & & $(0.0691)$ & $(0.0793)$ & $(0.0909)$ \\
\hline & Lending Mktshare $\mathrm{i,t}$ & 0.0564 & 0.0173 & 0.00949 \\
\hline & & $(0.0706)$ & $(0.0905)$ & $(0.0346)$ \\
\hline & Private Placement & $1.364 * * *$ & $1.006^{* * * *}$ & 0.675 \\
\hline & & $(0.219)$ & $(0.280)$ & $(0.461)$ \\
\hline & Multiple Uws & $-0.777 * * *$ & $-0.811^{* *}$ & $-1.477 * * *$ \\
\hline & & $(0.253)$ & $(0.333)$ & $(0.237)$ \\
\hline & UW size & $0.489 *$ & $0.709 *$ & $0.467 * * *$ \\
\hline & & $(0.292)$ & $(0.426)$ & $(0.0615)$ \\
\hline & ROE & 0.00102 & $0.00657 * * *$ & 0.00239 \\
\hline & & $(0.000681)$ & $(0.00253)$ & $(0.00166)$ \\
\hline & Liquidity & $0.00183 * * *$ & $0.00236^{* * *}$ & $0.00273 * * *$ \\
\hline & & $(0.000326)$ & $(0.000406)$ & $(0.000403)$ \\
\hline & Capital Adequacy & 0.00462 & 0.00601 & $0.00596 * * *$ \\
\hline & & $(0.00300)$ & $(0.00460)$ & $(0.000970)$ \\
\hline & Operation Efficiency & $0.00170 *$ & 0.00203 & $0.00354 * *$ \\
\hline & & $(0.000972)$ & $(0.00149)$ & $(0.00144)$ \\
\hline & Age & $0.371 * * *$ & $0.395 * * *$ & $0.366 * * *$ \\
\hline & & $(0.0471)$ & $(0.0548)$ & $(0.0631)$ \\
\hline & Listed & $0.624 * * *$ & $0.633^{* * *}$ & $0.944 * * *$ \\
\hline & & $(0.123)$ & $(0.142)$ & $(0.172)$ \\
\hline \multirow{12}{*}{ 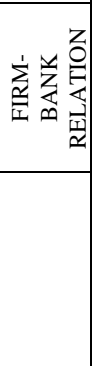 } & Firm - Bank Shared nationality & $1.581 * * *$ & $1.321 * * *$ & $1.648 * * *$ \\
\hline & & $(0.0748)$ & $(0.0925)$ & $(0.0782)$ \\
\hline & Prior Firm-UW Relationships & $2.220 * * *$ & $2.311 * * *$ & $4.140 * * *$ \\
\hline & & $(0.339)$ & $(0.440)$ & $(0.355)$ \\
\hline & Prior Firm-Lending Relationships & $9.507 * * *$ & $6.180 * * *$ & \\
\hline & & $(0.859)$ & $(0.796)$ & \\
\hline & Observations & 100,188 & 57,221 & 29,741 \\
\hline & Year & Yes & Yes & Yes \\
\hline & Firm & Yes & Yes & Yes \\
\hline & Pseudo $\mathrm{R}^{2}$ & 0.310 & 0.279 & 0.243 \\
\hline & Log-Likelihood & -13806.3 & -8692.5 & -3932.1 \\
\hline & p-value (chi2) & 0.00 & 0.00 & 0.00 \\
\hline
\end{tabular}


TABLE V

FIRM-BANK MATCHING: RETAINING A PRIOR MANDATE

This table presents the coefficients and the z-statistics for the conditional fixed effects logit regressions for the determinants of being retained as underwriter in a given deal. All variables are defined in the Appendix. Z-statistics are based on bond clustered standard errors. A constant term (not reported) is included in all regressions. *,**,*** Coefficients are statistically significant different than zero at least at $10 \%, 5 \%$ and $1 \%$.

\begin{tabular}{|c|c|c|c|c|}
\hline & \multirow[t]{2}{*}{ VARIABLES } & \multicolumn{3}{|c|}{ Dep. Var: UW Retained ( $0 \mid 1)$} \\
\hline & & $\begin{array}{l}\text { Firm-Bank Matching: } \\
\text { Retention }\end{array}$ & $\begin{array}{l}\text { Subsample: Firms issuing in } \\
\text { the pre-crisis \& crisis }\end{array}$ & $\begin{array}{l}\text { Subsample: Firms without } \\
\text { prior lending relationships }\end{array}$ \\
\hline & \multirow[t]{2}{*}{ Recapitalizedit } & -0.0585 & -0.0627 & 0.195 \\
\hline & & $(0.166)$ & $(0.239)$ & $(0.329)$ \\
\hline & \multirow[t]{2}{*}{ Reputable $_{i}$} & $0.414 * *$ & $0.552 * *$ & $0.561 *$ \\
\hline & & $(0.183)$ & $(0.229)$ & $(0.329)$ \\
\hline & \multirow[t]{2}{*}{ Recapitalizedit $_{x}$ Reputable $_{i}$} & $-0.539 * *$ & $-0.579 * *$ & $-0.947 * *$ \\
\hline & & $(0.228)$ & $(0.291)$ & $(0.451)$ \\
\hline \multirow{14}{*}{ 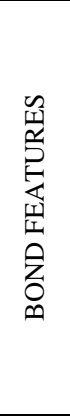 } & \multirow[t]{2}{*}{ Bond size } & $-0.386 * * *$ & $-0.309 * *$ & 0.0955 \\
\hline & & $(0.129)$ & $(0.143)$ & $(0.245)$ \\
\hline & \multirow[t]{2}{*}{ Maturity } & 0.134 & 0.313 & $0.751 *$ \\
\hline & & $(0.179)$ & $(0.215)$ & $(0.408)$ \\
\hline & \multirow[t]{2}{*}{ Callability } & 0.309 & 0.184 & $1.116^{* *}$ \\
\hline & & $(0.197)$ & $(0.255)$ & $(0.568)$ \\
\hline & \multirow[t]{2}{*}{ Domestic Placement } & 0.120 & 0.0781 & $12.46^{* * *}$ \\
\hline & & $(0.345)$ & $(0.463)$ & $(1.195)$ \\
\hline & Investment Grade & -0.751 & -0.540 & -0.906 \\
\hline & & $(0.583)$ & $(0.709)$ & $(0.772)$ \\
\hline & Collateral & 1.532 & $-11.22 * * *$ & -4.315 \\
\hline & & $(1.024)$ & $(1.155)$ & $(3.541)$ \\
\hline & Syndicate Size & $0.385 * * *$ & $0.380 * * *$ & $0.291 * * *$ \\
\hline & & $(0.0383)$ & $(0.0504)$ & $(0.0884)$ \\
\hline & Firm size & $-1.932 * *$ & -1.381 & $-4.565^{* *}$ \\
\hline & & $(0.844)$ & $(1.119)$ & $(2.027)$ \\
\hline$-\frac{\pi}{2}$ & Firm Leverage & -1.142 & 1.810 & 5.844 \\
\hline$\sum$ 当 & & $(2.231)$ & $(2.497)$ & $(5.927)$ \\
\hline 学毞 & Firm ROA & 0.00319 & 0.0303 & 0.0525 \\
\hline 空 & & $(0.0257)$ & $(0.0295)$ & $(0.0491)$ \\
\hline & First time issuer & 0.426 & 0.0209 & 0.153 \\
\hline & & $(0.327)$ & $(1.428)$ & $(0.666)$ \\
\hline & Abnormal Bond Spreads & -0.000850 & -0.00165 & 0.00125 \\
\hline & & $(0.00209)$ & $(0.00277)$ & $(0.00418)$ \\
\hline & Abnormal Fees & -1.139 & -1.566 & -0.211 \\
\hline & & $(1.168)$ & $(1.458)$ & $(2.206)$ \\
\hline & HHI Industry Specialization & $-1.89 \mathrm{e}-05$ & $4.38 \mathrm{e}-06$ & -0.000130 \\
\hline & & $(6.05 e-05)$ & $(7.40 \mathrm{e}-05)$ & $(0.000111)$ \\
\hline & Number Total Star Analyst $\mathrm{i}, \mathrm{t}-1$ & 0.0182 & $0.0331 *$ & 0.0315 \\
\hline & & $(0.0129)$ & $(0.0171)$ & $(0.0305)$ \\
\hline & UW Lender $i, t$ & 0.188 & -0.0186 & -0.0674 \\
\hline & & $(0.187)$ & $(0.217)$ & $(0.303)$ \\
\hline & Lending Mktshare $_{i, t}$ & 0.117 & 0.154 & 0.0365 \\
\hline & & $(0.0710)$ & $(0.0992)$ & $(0.172)$ \\
\hline 宓 & Private Placement & $-2.149 * *$ & -0.939 & $-3.341^{*}$ \\
\hline ? & & $(1.087)$ & $(1.452)$ & $(1.866)$ \\
\hline 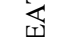 & Multiple Uws & $-1.919 * * *$ & $-3.012 * * *$ & -1.058 \\
\hline 㟔 & & $(0.594)$ & $(0.635)$ & (1.236) \\
\hline 光 & UW size & 0.0170 & -0.0358 & 0.115 \\
\hline Z & & $(0.0834)$ & $(0.139)$ & $(0.371)$ \\
\hline & ROE & -0.000132 & $-0.0188 * * *$ & -0.00854 \\
\hline & & $(0.00205)$ & $(0.00713)$ & $(0.0106)$ \\
\hline & Liquidity & $0.00267 * * *$ & $0.00299 * *$ & $0.0127^{*}$ \\
\hline & & $(0.00102)$ & $(0.00132)$ & $(0.00748)$ \\
\hline & Capital Adequacy & $0.0524 *$ & 0.0177 & 0.0402 \\
\hline & & $(0.0288)$ & $(0.0433)$ & $(0.0677)$ \\
\hline & Operation Efficiency & -0.00227 & $-0.00635 * *$ & -0.00651 \\
\hline & & $(0.00224)$ & $(0.00322)$ & $(0.00466)$ \\
\hline & Age & -0.0813 & $0.439 * *$ & 0.369 \\
\hline & & $(0.157)$ & $(0.208)$ & $(0.387)$ \\
\hline & Listed & $0.932 * *$ & $1.259 * *$ & 0.457 \\
\hline & & $(0.400)$ & $(0.559)$ & $(0.661)$ \\
\hline & Firm - Bank Shared nationality & $0.869 * * *$ & $0.883 * * *$ & $0.773^{* * *}$ \\
\hline 学云 & & $(0.138)$ & $(0.185)$ & $(0.295)$ \\
\hline 昏 & Prior Firm-UW Relationships & 0.604 & 0.211 & 1.955 \\
\hline$\sum_{2}^{T}$ & & $(0.524)$ & $(0.687)$ & $(1.199)$ \\
\hline$\frac{2}{a}$ & Prior Firm-Lending Relationships & $2.222 * * *$ & 0.949 & \\
\hline & & $(0.856)$ & $(0.723)$ & \\
\hline & Observations & 2,938 & 1,917 & 726 \\
\hline & Year Fixed Effects & Yes & Yes & Yes \\
\hline & Firm Fixed Effects & Yes & Yes & Yes \\
\hline & Pseudo $\mathrm{R}^{2}$ & 0.113 & 0.123 & 0.156 \\
\hline & Log-Likelihood & -1092.8 & -710.6 & -263.8 \\
\hline & p-value (chi2) & 0.00 & 0.00 & 0.00 \\
\hline
\end{tabular}


TABLE VI

CONTINUOUS MEASURES OF REPUTATION

This table presents the coefficients for the difference-in-differences estimations for underwriter market shares for fixed corporate bonds in Europe from 2006-2013. The dependent variable is underwriter market share computed on a proceeds base, in which proceeds of syndicated bonds are split among all the underwriters. In Column I, the total proceeds raised in the corporate bond markets by each underwriter during the pre-bailout period (UW-proceeds) are considered as reputation measure. In Column II, the inverse of the raking position hold by the underwriter in the league tables during the pre-bailout period (UW-inv.ranking) is used as reputation measure. In Column III, the Megginson-Weiss measure computed during the pre-bailout period is used as reputation measure. A constant term (not reported) is included in all regressions. Z-statistics are based on underwriter clustered standard errors. *, **, *** Coefficients are statistically significant different than zero at least at $10 \%, 5 \%$ and $1 \%$ levels.

\begin{tabular}{|c|c|c|c|}
\hline \multirow{2}{*}{$\begin{array}{l}\text { Dependent Variable: } \\
\text { Mkt. share Proceeds Apportioned }\end{array}$} & \multicolumn{3}{|c|}{ Continuous reputation measure } \\
\hline & UW-proceeds & UW-inv.ranking & UW-MW \\
\hline Recapitalized $_{\text {it }}$ x Reputation measure R $_{i}$ & $\begin{array}{c}-0.112 * * * \\
(0.0407)\end{array}$ & $\begin{array}{c}-8.667 * * * \\
(0.998)\end{array}$ & $\begin{array}{r}-0.0177 * * \\
(0.00840)\end{array}$ \\
\hline Controls & Yes & Yes & Yes \\
\hline Time Fixed Effects & Yes & Yes & Yes \\
\hline UW Fixed Effects & Yes & Yes & Yes \\
\hline F-test & 0.00 & 0.00 & 0.00 \\
\hline
\end{tabular}

TABLE VII

\section{ALTERNATIVE MEASURES OF REPUTATION}

This table presents the coefficients for the difference-in-differences estimations for underwriter market shares for fixed corporate bonds in Europe from 2006-2013. The dependent variable is underwriter market share computed on a proceeds base, in which proceeds of syndicated bonds are split among all the underwriters. Panel A measures reputation based on deals issued by high-quality firms. Panel B measures reputation based on the presence of star fixed income analysts working for the underwriter. All the discrete and continuous measures considered in each regression are described in the Appendix Table A.II. A constant term (not reported) is included in all regressions. Z-statistics are based on underwriter clustered standard errors. $*, * *, * *$ Coefficients are statistically significant different than zero at least at $10 \%, 5 \%$ and $1 \%$ levels.

\begin{tabular}{|c|c|c|c|c|}
\hline \multirow{3}{*}{$\begin{array}{l}\text { Panel A. } \\
\text { Dependent Variable: } \\
\text { Mkt. share Proceeds Apportioned }\end{array}$} & \multicolumn{4}{|c|}{ Alt. Reputation measure: High Quality firms } \\
\hline & & \multicolumn{3}{|c|}{ Continuous measures } \\
\hline & Top 5 & UW-proceeds & UW-inv. ranking & $\mathbf{U W - M W}$ \\
\hline \multirow{2}{*}{$\begin{array}{l}\text { Recapitalized }_{\text {it }} \\
\text { Recapitalized }_{\text {it }} \text { x Reputation measure } \\
\text { Re }\end{array}$} & $\begin{array}{l}0.263 * * \\
(0.116)\end{array}$ & $\begin{array}{l}0.449 * * * \\
(0.122)\end{array}$ & $\begin{array}{l}0.724 * * * \\
(0.132)\end{array}$ & $\begin{array}{l}0.305 * * \\
(0.133)\end{array}$ \\
\hline & $\begin{array}{c}-3.473 * * * \\
(0.415)\end{array}$ & $\begin{array}{c}-5.76 \mathrm{e}-10 * * * \\
(6.59 \mathrm{e}-11)\end{array}$ & $\begin{array}{l}-9.758 * * * \\
(1.040)\end{array}$ & $\begin{array}{c}-0.0102 * * * \\
(0.00238)\end{array}$ \\
\hline Controls & Yes & Yes & Yes & Yes \\
\hline $\begin{array}{l}\text { Time Fixed Effects } \\
\text { UW Fixed Effects }\end{array}$ & $\begin{array}{l}\text { Yes } \\
\text { Yes }\end{array}$ & $\begin{array}{l}\text { Yes } \\
\text { Yes }\end{array}$ & $\begin{array}{l}\text { Yes } \\
\text { Yes }\end{array}$ & $\begin{array}{l}\text { Yes } \\
\text { Yes }\end{array}$ \\
\hline $\begin{array}{l}\text { F-test } \\
\text { Observations } \\
\text { R-squared }\end{array}$ & $\begin{array}{c}0.00 \\
833 \\
0.270\end{array}$ & $\begin{array}{c}0.00 \\
833 \\
0.572\end{array}$ & $\begin{array}{c}0.00 \\
833 \\
0.240\end{array}$ & $\begin{array}{c}0.00 \\
833 \\
0.178\end{array}$ \\
\hline \multicolumn{5}{|l|}{ Panel B. } \\
\hline \multirow{2}{*}{$\begin{array}{l}\text { Dependent Variable: } \\
\text { Mkt. share Proceeds Apportioned }\end{array}$} & & \multicolumn{3}{|c|}{ Continuous measures } \\
\hline & Top 5 & $\mathbf{N}^{\circ}$ Star Analysts & Inv. ranking & MW \\
\hline Recapitalized $_{\text {it }}$ & $\begin{array}{l}0.109 * \\
(0.101)\end{array}$ & $\begin{array}{c}0.220 * * \\
(0.069)\end{array}$ & $\begin{array}{c}0.342 * * \\
(0.136)\end{array}$ & $\begin{array}{c}0.223 * * \\
(0.067)\end{array}$ \\
\hline Recapitalized $_{\text {it }}$ X Reputation measure ${ }_{i}$ & $\begin{array}{c}-1.256 * * * \\
(0.437)\end{array}$ & $\begin{array}{c}-0.0268 * * * \\
(0.00634)\end{array}$ & $\begin{array}{c}-2.768 * * * \\
(0.633)\end{array}$ & $\begin{array}{c}-0.0108 * * * \\
(0.00329)\end{array}$ \\
\hline Controls & Yes & Yes & Yes & Yes \\
\hline $\begin{array}{l}\text { Time Fixed Effects } \\
\text { UW Fixed Effects }\end{array}$ & $\begin{array}{l}\text { Yes } \\
\text { Yes }\end{array}$ & $\begin{array}{l}\text { Yes } \\
\text { Yes }\end{array}$ & $\begin{array}{l}\text { Yes } \\
\text { Yes }\end{array}$ & $\begin{array}{l}\text { Yes } \\
\text { Yes }\end{array}$ \\
\hline $\begin{array}{l}\text { F-test } \\
\text { Observations } \\
\text { R-squared }\end{array}$ & $\begin{array}{c}0.00 \\
833 \\
0.293\end{array}$ & $\begin{array}{c}0.00 \\
833 \\
0.245\end{array}$ & $\begin{array}{c}0.00 \\
833 \\
0.263\end{array}$ & $\begin{array}{c}0.00 \\
833 \\
0.243\end{array}$ \\
\hline
\end{tabular}


FIGURE IV.

\section{THE REPUTATIONAL CUTOFF}

These figures plot the coefficients for difference-in-difference regressions. Figure IV.a (left-hand side) plots the DID coefficients extending the criteria used to be defined as reputable underwriter (Top 5, 10, 15 and 20). Figure IV.b (right-hand side) plots the DID coefficients considering different sub-groups of banks (Top 1-5, 5-10, 10-15 and 15-20).
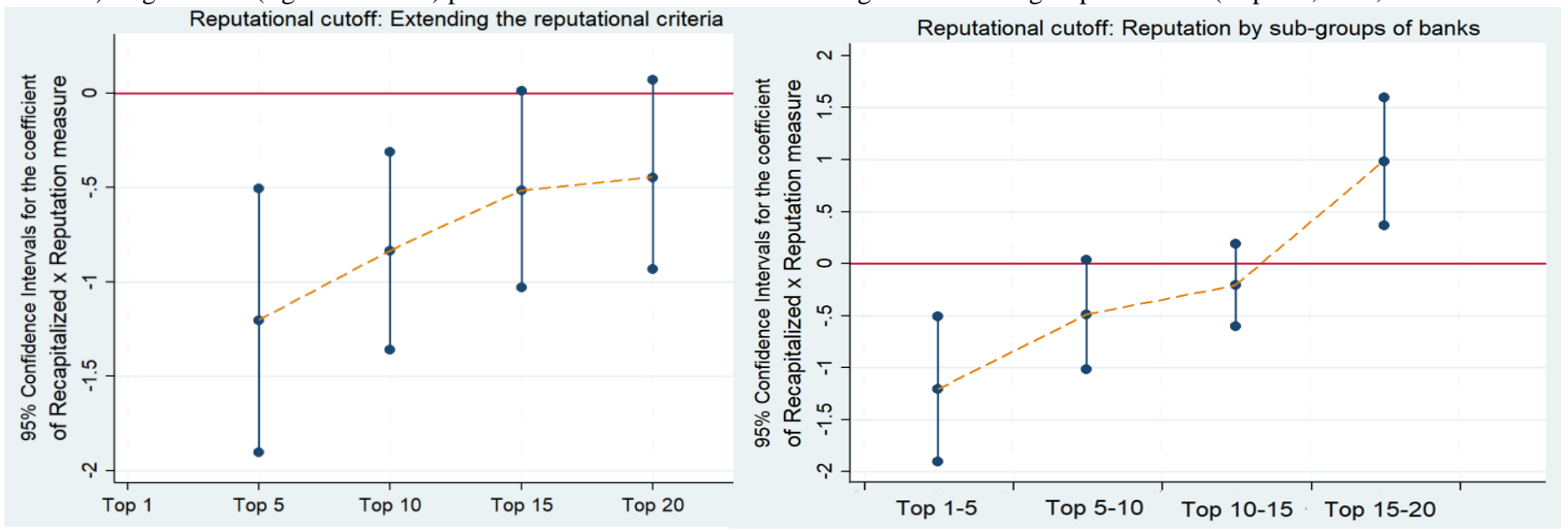

\section{TABLE VIII}

\section{ROBUSTNESS CHECKS IN DIFFERENCE-IN-DIFFERENCES REGRESSIONS ON UNDERWRITER MARKET SHARES}

This table presents the coefficients for the difference-in-differences estimations for underwriter market shares for fixed corporate bonds in Europe from 2006-2013. Column I and II present the results using alternative market share measures. Column III and IV present the results for a subsample of active underwriters placing at least one bond per year. Columns V to VIII present the results using alternative reputation measures. In Column V and VI underwriters are randomly assigned as recapitalized or not and errors are obtained with bootstrapped confidence intervals using 2,500 replications. In Columns VII and VIII, it is artificially assumed that each of the bailout measures took place two years earlier. In Columns IX and X the recapitalization measure used is the ratio of total funds received by the underwriter to total assets. In Columns XI and XII the recapitalization measure used is the natural logarithm of the total funds received by the underwriter plus one. The reputation measure considered is a dummy that takes the value 1 if the underwriter if the underwriter bank is ranked in the top five in the annual league tables considering the market shares of the pre-bailout period A constant term (not reported) is included in all regressions. Z-statistics are based on underwriter clustered standard errors. $* * *, * * *$ Coefficients are statistically significant different than zero at least at $10 \%, 5 \%$ and $1 \%$ levels.

\begin{tabular}{|c|c|c|c|c|c|c|c|c|c|c|c|c|}
\hline \multirow[b]{3}{*}{ Dependent Variable: } & \multicolumn{2}{|c|}{$\begin{array}{l}\text { Alternative market } \\
\text { share measures }\end{array}$} & \multirow{2}{*}{\multicolumn{2}{|c|}{$\begin{array}{c}\begin{array}{l}\text { Subsample Active } \\
\text { Underwriters }\end{array} \\
\text { Dep. Var: Mkt. share } \\
\text { Proceeds Apportioned }\end{array}$}} & \multirow{2}{*}{\multicolumn{4}{|c|}{$\begin{array}{c}\text { Placebo Experiments } \\
\text { Dep. Var: Mkt. share Proceeds Apportioned }\end{array}$}} & \multirow{2}{*}{\multicolumn{4}{|c|}{$\begin{array}{c}\text { Intensity of the Recapitalization Measure } \\
\text { Dep. Var: Mkt. share Proceeds Apportioned }\end{array}$}} \\
\hline & \multirow{2}{*}{\multicolumn{2}{|c|}{$\begin{array}{l}\text { Dep. Var: } \quad \text { Dep. Var: } \\
\text { Mkt. share proceeds full }\end{array}$}} & & & & & & & & & & \\
\hline & & & \multicolumn{2}{|c|}{$\mathbf{N}^{\circ}$ deals $>0$} & \multicolumn{2}{|c|}{$\begin{array}{l}\text { Random assignment of } \\
\text { Recapitalized Underwriters }\end{array}$} & \multicolumn{2}{|c|}{$\begin{array}{c}\text { Fake Recapitalization } \\
\text { period }\end{array}$} & \multicolumn{2}{|c|}{$\begin{array}{c}\text { Recapitalized }= \\
\text { Recapitalization intensity } \\
\text { Recapitalization Amount } \\
\text { Total Assets }\end{array}$} & \multicolumn{2}{|c|}{$\begin{array}{c}\text { Recapitalized }=\text { Recapitalization } \\
\text { amount } \\
\text { Ln }(1+\text { Recapitalization } \\
\text { amount }) \\
\end{array}$} \\
\hline Recapitalizedit $_{\text {it }}$ & $\begin{array}{l}0.0771 \\
(0.122)\end{array}$ & $\begin{array}{l}0.218^{*} \\
(0.123)\end{array}$ & $\begin{array}{c}0.362 \\
(0.269)\end{array}$ & $\begin{array}{l}0.613^{* *} \\
(0.282)\end{array}$ & $\begin{array}{l}-0.00794 \\
(0.0635)\end{array}$ & $\begin{array}{l}-0.00632 \\
(0.0652)\end{array}$ & $\begin{array}{l}-0.00594 \\
(0.133)\end{array}$ & $\begin{array}{l}-0.0723 \\
(0.167)\end{array}$ & $\begin{array}{c}1.113 \\
(1.465)\end{array}$ & $\begin{array}{l}1.925 * \\
(1.449)\end{array}$ & $\begin{array}{c}0.0222 \\
(0.0138)\end{array}$ & $\begin{array}{c}0.0292 * * \\
(0.0141)\end{array}$ \\
\hline Recapitalized $_{\text {it }} \times$ Reputable $_{i}$ & & $\begin{array}{c}-1.360^{* * * *} \\
(0.363)\end{array}$ & & $\begin{array}{c}-1.404 * * * \\
(0.529)\end{array}$ & & $\begin{array}{l}-0.0319 \\
(0.290)\end{array}$ & & $\begin{array}{l}1.207 \\
(1.464)\end{array}$ & & $\begin{array}{c}-31.08 * * \\
(14.48)\end{array}$ & & $\begin{array}{c}-0.0612^{* *} \\
(0.0355)\end{array}$ \\
\hline Controls & Yes & Yes & Yes & Yes & Yes & Yes & Yes & Yes & Yes & Yes & Yes & Yes \\
\hline Time Fixed Effects & Yes & Yes & Yes & Yes & Yes & Yes & Yes & Yes & Yes & Yes & Yes & Yes \\
\hline UW Fixed Effects & Yes & Yes & Yes & Yes & Yes & Yes & Yes & Yes & Yes & Yes & Yes & Yes \\
\hline F-test & 0.000 & 0.000 & 0.000 & 0.000 & 0.000 & 0.000 & 0.000 & 0.000 & 0.000 & 0.000 & 0.000 & 0.000 \\
\hline Observations & 833 & 833 & 436 & 436 & 794 & 833 & 833 & 833 & 833 & 833 & 833 & 833 \\
\hline R-squared & 0.444 & 0.454 & 0.285 & 0.261 & 0.399 & 0.399 & 0.453 & 0.493 & 0.514 & 0.492 & 0.513 & 0.510 \\
\hline
\end{tabular}




\section{TABLE IX}

ROBUSTNESS: TWO-STAGE HECKMAN'S MODEL FOR SELF-SELECTION BIASES

This table presents the coefficients for the two-stage Heckman's (1979) self-selection model. In the first stage the dependent variable is a dummy that takes the value 1 if the underwriter is being recapitalized. In the second stage the dependent variable is underwriter market share computed on a proceeds base, in which proceeds of syndicated bonds are split among all the underwriters. All the explanatory variables are described in the Appendix. A constant term (not reported) is included in all regressions. Z-statistics are based on underwriter clustered standard errors. ${ }^{*}, * *$ $* * *$ Coefficients are statistically significant different than zero at least at $10 \%, 5 \%$ and $1 \%$ levels.

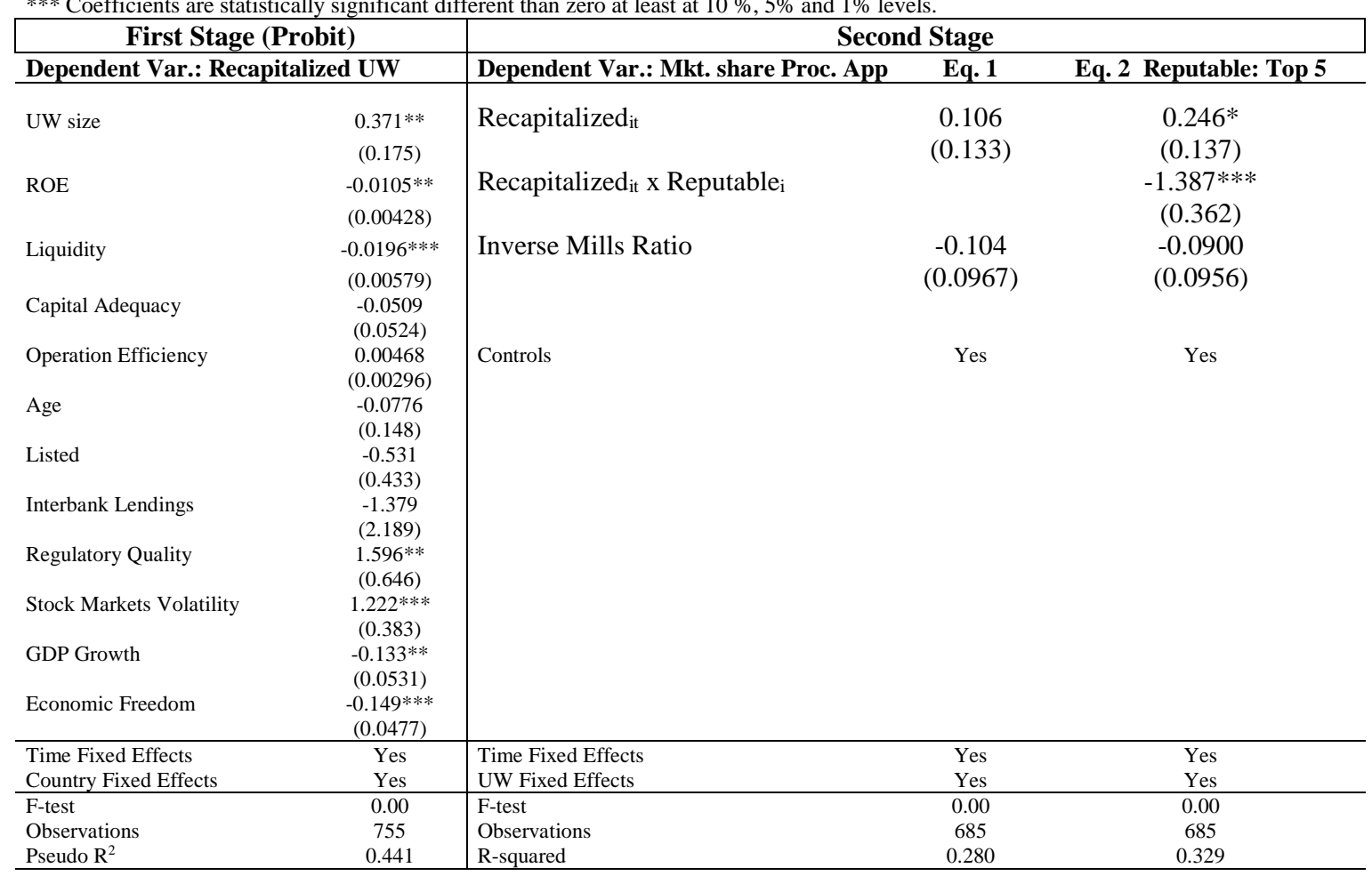

\section{TABLE X}

ROBUSTNESS: INSTRUMENTAL VARIABLE ANALYSIS

This table presents the coefficients for the difference-in-differences estimations for underwriter market shares for fixed corporate bonds in Europe from 2006-2013 using an IV approach. The dependent variable is underwriter market share computed on a proceeds base, in which proceeds of syndicated bonds are split among all the underwriters. We use as instruments: Pol_Reg connection, Prompt corrective power index and Bank opacity. Panel A reports first-stage results. Panel B reports second-stage regression estimates. All the instruments are described in the Appendix. A constant term (not reported) is included in all regressions. Z-statistics are based on underwriter clustered standard errors. *, **, *** Coefficients are statistically significant different than zero at least at $10 \%, 5 \%$ and $1 \%$ levels.

\begin{tabular}{|c|c|}
\hline \multicolumn{2}{|c|}{ Panel A. Instrumental Variable Estimator First Stage: Instruments } \\
\hline \multicolumn{2}{|c|}{\begin{tabular}{|l|l} 
Dependent Variable: Recapitalized Underwriter & \\
\end{tabular}} \\
\hline Pol_Reg connection & $\begin{array}{l}1.909 * * * \\
(0.1573)\end{array}$ \\
\hline Prompt corrective power index & $-0.058 * * *$ \\
\hline & $(0.0271)$ \\
\hline Bank opacity & $-0.586 * *$ \\
\hline Controls & Yes \\
\hline Time Fixed Effects & Yes \\
\hline First-stage F-test (instruments) & 20.05 \\
\hline Kleibergen-Paap weak identification F-statistic & 20.17 \\
\hline Observations & 833 \\
\hline Recapitalized $_{\text {it }}$ & $\begin{array}{c}0.433 * * \\
(0.167)\end{array}$ \\
\hline Recapitalized $_{\text {it }} \mathrm{x}$ Reputation measure $_{\mathrm{i}}$ & $-1.837 * * *$ \\
\hline & $(0.473)$ \\
\hline Controls & Yes \\
\hline Time Fixed Effects & Yes \\
\hline UW Fixed Effects & Yes \\
\hline F-test & 0.00 \\
\hline Observations & 833 \\
\hline R-squared & 0.405 \\
\hline
\end{tabular}


TABLE XI

ROBUSTNESS: CLASSICAL DID APPROACH (TRIPLE DIFFERENCES)

This table presents the coefficients for the difference-in-differences estimations for underwriter market shares for fixed corporate bonds in Europe from 2006-2013. The dependent variable is underwriter market share computed on a proceeds base, in which proceeds of syndicated bonds are split among all the underwriters. Post-Bailout $t_{t} x$ Recapitalized $_{i} x$ Reputable $_{i}$ reflects the incremental effect on reputable underwriters. Z-statistics are based on underwriter clustered standard errors. A constant term (not reported) is included in all regressions. $* * *, * * *$ Coefficients are statistically significant different than zero at least at $10 \%, 5 \%$ and $1 \%$ levels.

Equation 2

Dependent Variable: Mkt. share Proceeds Apportioned Reputable: Top 5

Recapitalized $_{i}$

$-0.505^{* *}$

(0.208)

Reputable $_{i}$

$3.210 * *$

249)

Reputable $_{i} \times$ Recapitalized $_{i}$

0.179

Post-Bailout $_{t}$ x Reputable Re $_{i}$

(0.740)

$-0.415$

(1.199)

$0.416 * *$

Post-Bailout $_{t} x$ Recapitalized $_{i}$

(0.166)

Post-Bailout $_{t} \times$ Recapitalized $_{i} \times$ Reputable $_{i}$

(1.144)

Controls Yes

Time Fixed Effects Yes

\begin{tabular}{lr} 
Country Fixed Effects & Yes \\
\hline
\end{tabular}

\begin{tabular}{lr}
\hline F-test & 0.000
\end{tabular}

$\begin{array}{lr}\text { Observations } & 794\end{array}$

R-squared

0.848

\section{TABLE XII}

ROBUSTNESS: MATCHED DIFFERENCE-IN-DIFFERENCES

This table presents the coefficients for the matched differences-in-differences estimations for underwriter market shares for fixed corporate bonds in Europe from 2006-2013. The dependent variable is underwriter market share computed on a proceeds base, in which proceeds of syndicated bonds are split among all the underwriters. Z-statistics are based on underwriter clustered standard errors. A constant term (not reported) is included in all regressions. *, **, *** Coefficients are statistically significant different than zero at least at $10 \%, 5 \%$ and $1 \%$ levels.

\begin{tabular}{lr}
\hline Dependent Variable: Mkt. share Proceeds Apportioned & $\begin{array}{c}\text { Equation 2 } \\
\text { Reputable: Top 5 }\end{array}$ \\
\hline Recapitalized $_{i t}$ & $0.243 * * *$ \\
& $(0.053)$ \\
Recapitalized $_{\text {it }}$ Reputable & $-0.446^{* * *}$ \\
& $(0.1539)$ \\
Controls & Yes \\
\hline Time-cohort period fixed effects & Yes \\
UW-cohort fixed effects & Yes \\
\hline F-test & 0.000 \\
Observations & 4,757 \\
R-squared & 0.901 \\
\hline
\end{tabular}




\section{APPENDIX A}

TABLE A.I.

NATIONAL RANKING LEAGUE TABLES BY MARKET SHARE ( $<1 \%$ Mkt. share)

Underwriter

Mitsubishi UFJ Financial Group

RBC Capital Markets

Mizuho

LBBW

SEB

Nordea Markets

BayernLB

Danske Bank

Merrill Lynch

DZ Bank

TD Securities Inc

$\mathrm{KBC}$

ABN AMRO

Erste Group Bank AG

Raiffeisen Bank International AG

Mediobanca

Lehman Brothers

Bank of America

Standard Chartered Bank

Rabobank

CaixaBank

Nomura

Svenska Handelsbanken AB

Belfius Bank \& Insurance

Fortis

OP-Pohjola Group

CM-CIC

Dresdner Kleinwort

Caja Madrid - Bankia

Sumitomo Mitsui Financial Group

Close Brothers Group plc

KKR

WestLB

CaixaBI

Wells Fargo Securities

Monte dei Paschi

Jefferies LLC

Helaba

Pareto Securities

ANZ

Swedbank

Centrobanca SpA

Banco Espirito Santo

Canaccord Genuity Corp

Daiwa Securities

Commonwealth Bank of Australia

Dexia

Scotiabank

National Australia Bank

Millennium Investment Banking

Banco BPI

DNB Markets

CIBC World Markets

Oddo \& Cie

Banca March SA

TradeRisks Ltd

Banca Akros

IKB Deutsche Industriebank

BAWAG

\begin{tabular}{|c|c|c|c|c|c|}
\hline France & Germany & Kingdom & Italy & Spain & Europe \\
\hline 2.1024 & 0.2166 & 1.3119 & 0.3456 & 0.4112 & 0.9467 \\
\hline 0.8896 & 1.3463 & 1.1737 & 0.0000 & 0.0000 & 0.8117 \\
\hline 0.6067 & 0.5094 & 1.5551 & 0.0920 & 0.0000 & 0.6872 \\
\hline 0.0000 & 2.7201 & 0.0000 & 0.0000 & 0.0000 & 0.6038 \\
\hline 0.0000 & 0.3290 & 0.0000 & 0.0000 & 0.0000 & 0.5681 \\
\hline 0.0000 & 0.1655 & 0.1047 & 0.0000 & 0.0000 & 0.5363 \\
\hline 0.1319 & 2.1514 & 0.0000 & 0.0000 & 0.0000 & 0.5071 \\
\hline 0.0000 & 0.6159 & 0.0647 & 0.0000 & 0.0000 & 0.4723 \\
\hline 0.5308 & 0.1725 & 0.2745 & 0.2943 & 0.0000 & 0.4213 \\
\hline 0.0000 & 1.4491 & 0.0000 & 0.0000 & 0.0000 & 0.3761 \\
\hline 0.4086 & 0.6763 & 0.2060 & 0.0000 & 0.0000 & 0.3447 \\
\hline 0.0616 & 0.0031 & 0.0336 & 0.0000 & 0.0000 & 0.3440 \\
\hline 0.5929 & 0.0752 & 0.2039 & 0.3370 & 0.0000 & 0.3425 \\
\hline 0.0000 & 0.0701 & 0.0000 & 0.0000 & 0.0000 & 0.3302 \\
\hline 0.0000 & 0.1882 & 0.0000 & 0.0000 & 0.0000 & 0.3220 \\
\hline 0.1639 & 0.1093 & 0.0000 & 3.4205 & 0.0000 & 0.3048 \\
\hline 0.0000 & 0.0000 & 0.9430 & 0.0000 & 0.0000 & 0.2437 \\
\hline 0.0000 & 0.1000 & 0.5177 & 0.0000 & 1.1915 & 0.2335 \\
\hline 0.0382 & 0.1756 & 0.6528 & 0.0000 & 0.0000 & 0.2132 \\
\hline 0.0535 & 0.0464 & 0.0000 & 0.0522 & 0.0000 & 0.1994 \\
\hline 0.0000 & 0.0000 & 0.0000 & 0.0000 & 3.3595 & 0.1511 \\
\hline 0.0431 & 0.1624 & 0.1177 & 0.2199 & 0.2915 & 0.1459 \\
\hline 0.0000 & 0.0433 & 0.0000 & 0.0000 & 0.0000 & 0.1412 \\
\hline 0.0000 & 0.0000 & 0.0000 & 0.0000 & 0.0000 & 0.1367 \\
\hline 0.0000 & 0.0000 & 0.0000 & 0.0000 & 0.0000 & 0.1316 \\
\hline 0.0000 & 0.0000 & 0.0000 & 0.0000 & 0.0000 & 0.1231 \\
\hline 0.5484 & 0.0000 & 0.0000 & 0.0000 & 0.0000 & 0.1228 \\
\hline 0.3122 & 0.2255 & 0.0000 & 0.0000 & 0.0000 & 0.1200 \\
\hline 0.0000 & 0.0000 & 0.0000 & 0.0000 & 3.4035 & 0.1136 \\
\hline 0.2888 & 0.1481 & 0.0000 & 0.0000 & 0.0000 & 0.1115 \\
\hline 0.0000 & 0.4713 & 0.0000 & 0.0000 & 0.0000 & 0.1090 \\
\hline 0.0822 & 0.0922 & 0.0312 & 0.0000 & 0.2915 & 0.1021 \\
\hline 0.0000 & 0.4158 & 0.0000 & 0.0000 & 0.0000 & 0.0979 \\
\hline 0.0000 & 0.0000 & 0.0000 & 0.0000 & 0.3986 & 0.0856 \\
\hline 0.0000 & 0.0338 & 0.3041 & 0.0000 & 0.0000 & 0.0847 \\
\hline 0.0000 & 0.0000 & 0.0000 & 1.4594 & 0.0000 & 0.0805 \\
\hline 0.0000 & 0.2075 & 0.0000 & 0.0000 & 0.0000 & 0.0777 \\
\hline 0.0000 & 0.3095 & 0.0000 & 0.0000 & 0.0000 & 0.0687 \\
\hline 0.0000 & 0.0000 & 0.1490 & 0.0000 & 0.0000 & 0.0687 \\
\hline 0.0199 & 0.0367 & 0.1831 & 0.0000 & 0.0000 & 0.0591 \\
\hline 0.0000 & 0.0000 & 0.0000 & 0.0000 & 0.0000 & 0.0487 \\
\hline 0.0000 & 0.0000 & 0.0000 & 0.8555 & 0.0000 & 0.0472 \\
\hline 0.0000 & 0.0000 & 0.0000 & 0.0000 & 0.3986 & 0.0442 \\
\hline 0.0000 & 0.0000 & 0.1602 & 0.0000 & 0.0000 & 0.0407 \\
\hline 0.1351 & 0.0062 & 0.0000 & 0.0000 & 0.0000 & 0.0316 \\
\hline 0.0265 & 0.0000 & 0.0983 & 0.0000 & 0.0000 & 0.0309 \\
\hline 0.0995 & 0.0000 & 0.0000 & 0.0000 & 0.0000 & 0.0281 \\
\hline 0.0000 & 0.0000 & 0.0554 & 0.0000 & 0.0000 & 0.0280 \\
\hline 0.0000 & 0.0063 & 0.0926 & 0.0000 & 0.0000 & 0.0249 \\
\hline 0.0000 & 0.0000 & 0.0000 & 0.0000 & 0.0000 & 0.0239 \\
\hline 0.0000 & 0.0000 & 0.0000 & 0.0000 & 0.0000 & 0.0232 \\
\hline 0.0000 & 0.0000 & 0.0000 & 0.0000 & 0.0000 & 0.0227 \\
\hline 0.0194 & 0.0270 & 0.0477 & 0.0000 & 0.0000 & 0.0224 \\
\hline 0.0996 & 0.0000 & 0.0000 & 0.0000 & 0.0000 & 0.0223 \\
\hline 0.0000 & 0.0000 & 0.0000 & 0.0000 & 0.7833 & 0.0217 \\
\hline 0.0000 & 0.0000 & 0.0805 & 0.0000 & 0.0000 & 0.0204 \\
\hline 0.0000 & 0.0000 & 0.0000 & 0.3689 & 0.0000 & 0.0203 \\
\hline 0.0000 & 0.0459 & 0.0000 & 0.1690 & 0.0000 & 0.0195 \\
\hline 0.0000 & 0.0000 & 0.0000 & 0.0000 & 0.0000 & 0.0190 \\
\hline
\end{tabular}


Alpha Bank AE

Eurobank Ergasias SA

Industrial \& Com. Bank of China- ICBC

Bank of China

Macquarie Group

BMO Capital Markets

DBS

Raiffeisenlandesbank Oberoesterreich

National Bank of Greece

Quirin Bank AG

Petercam

Steubing AG

Investec Bank

Westpac

APG Algemene Pensioen Groep NV

Itau BBA

Cecabank SA

Banco de Sabadell SA

Astrup Fearnley AS

GMP Capital Inc

Nova Ljubljanska Banka

Banco Popular Espanol SA

Banco Espirito Santo de Investimento

China Construction Bank Corp - CCB

Zuercher Kantonalbank - ZKB

Renta 4

MM Warburg

Bankinter

Abanka Vipa

Vontobel

Privatbanka as

Ahorro Corporacion Financiera SA

Banco Caminos SA

Banco Grupo Cajatres SA

Sociedad General de Valores y Cambios

Privredna Banka Zagreb

National Bank Financial

EuroLand Finance SA

Parex Banka

\begin{tabular}{|c|c|c|c|c|c|}
\hline 0.0000 & 0.0000 & 0.0000 & 0.0000 & 0.0000 & 0.0183 \\
\hline 0.0000 & 0.0000 & 0.0000 & 0.0000 & 0.0000 & 0.0183 \\
\hline 0.0606 & 0.0000 & 0.0162 & 0.0000 & 0.0000 & 0.0177 \\
\hline 0.0382 & 0.0218 & 0.0162 & 0.0000 & 0.0000 & 0.0175 \\
\hline 0.0000 & 0.0000 & 0.0579 & 0.0000 & 0.0000 & 0.0147 \\
\hline 0.0000 & 0.0031 & 0.0000 & 0.0000 & 0.0000 & 0.0146 \\
\hline 0.0000 & 0.0000 & 0.0000 & 0.0000 & 0.0000 & 0.0140 \\
\hline 0.0000 & 0.0000 & 0.0000 & 0.0000 & 0.0000 & 0.0122 \\
\hline 0.0000 & 0.0000 & 0.0000 & 0.0000 & 0.0000 & 0.0110 \\
\hline 0.0000 & 0.0486 & 0.0000 & 0.0000 & 0.0000 & 0.0108 \\
\hline 0.0000 & 0.0000 & 0.0000 & 0.0000 & 0.0000 & 0.0108 \\
\hline 0.0000 & 0.0202 & 0.0000 & 0.0000 & 0.0000 & 0.0101 \\
\hline 0.0000 & 0.0000 & 0.0375 & 0.0000 & 0.0000 & 0.0095 \\
\hline 0.0000 & 0.0425 & 0.0000 & 0.0000 & 0.0000 & 0.0094 \\
\hline 0.0000 & 0.0000 & 0.0000 & 0.0000 & 0.0000 & 0.0083 \\
\hline 0.0000 & 0.0000 & 0.0000 & 0.0000 & 0.2766 & 0.0077 \\
\hline 0.0000 & 0.0000 & 0.0000 & 0.0000 & 0.2677 & 0.0074 \\
\hline 0.0000 & 0.0000 & 0.0000 & 0.0000 & 0.2559 & 0.0071 \\
\hline 0.0000 & 0.0000 & 0.0000 & 0.0000 & 0.0000 & 0.0068 \\
\hline 0.0000 & 0.0000 & 0.0248 & 0.0000 & 0.0000 & 0.0063 \\
\hline 0.0000 & 0.0000 & 0.0000 & 0.0000 & 0.0000 & 0.0059 \\
\hline 0.0000 & 0.0000 & 0.0000 & 0.0000 & 0.2025 & 0.0056 \\
\hline 0.0000 & 0.0000 & 0.0000 & 0.0000 & 0.0000 & 0.0054 \\
\hline 0.0000 & 0.0201 & 0.0000 & 0.0000 & 0.0000 & 0.0045 \\
\hline 0.0000 & 0.0193 & 0.0000 & 0.0000 & 0.0000 & 0.0043 \\
\hline 0.0000 & 0.0000 & 0.0000 & 0.0000 & 0.1330 & 0.0037 \\
\hline 0.0000 & 0.0165 & 0.0000 & 0.0000 & 0.0000 & 0.0037 \\
\hline 0.0000 & 0.0000 & 0.0000 & 0.0000 & 0.1288 & 0.0036 \\
\hline 0.0000 & 0.0000 & 0.0000 & 0.0000 & 0.0000 & 0.0033 \\
\hline 0.0000 & 0.0125 & 0.0000 & 0.0000 & 0.0000 & 0.0028 \\
\hline 0.0000 & 0.0000 & 0.0000 & 0.0000 & 0.0000 & 0.0025 \\
\hline 0.0000 & 0.0000 & 0.0000 & 0.0000 & 0.0871 & 0.0024 \\
\hline 0.0000 & 0.0000 & 0.0000 & 0.0000 & 0.0871 & 0.0024 \\
\hline 0.0000 & 0.0000 & 0.0000 & 0.0000 & 0.0871 & 0.0024 \\
\hline 0.0000 & 0.0000 & 0.0000 & 0.0000 & 0.0871 & 0.0024 \\
\hline 0.0000 & 0.0000 & 0.0000 & 0.0000 & 0.0000 & 0.0016 \\
\hline 0.0000 & 0.0031 & 0.0000 & 0.0000 & 0.0000 & 0.0007 \\
\hline 0.0028 & 0.0000 & 0.0000 & 0.0000 & 0.0000 & 0.0006 \\
\hline 0.0000 & 0.0000 & 0.0000 & 0.0000 & 0.0000 & 0.0003 \\
\hline-2.30 & 0.5511 & -1.64 & -1.03 & -1.0310 & \\
\hline 686.628 & 622.920 & 639.836 & 702.265 & 558.544 & 477.218 \\
\hline 3.506 & 3.214 & 3.156 & 4.390 & 4.508 & 3.185 \\
\hline $2.64 \%$ & $1.84 \%$ & $0.38 \%$ & $7.14 \%$ & $5.44 \%$ & $3.66 \%$ \\
\hline 7 & 11 & 7 & 6 & 14 & - \\
\hline 8 & 12 & 11 & 6 & 7 & 13 \\
\hline
\end{tabular}




\section{TABLE A.II. \\ DESCRIPTION OF THE VARIABLES}

Panel A. Main Variables

\begin{tabular}{|c|c|}
\hline$\underline{\text { Variable }}$ & $\underline{\text { Description }}$ \\
\hline $\begin{array}{l}\text { Mkt. share / Mkt.share proc. } \\
\text { App. }\end{array}$ & $\begin{array}{l}\text { Market share computed on annual proceeds raised in the corporate bond markets (in case of more underwriters } \\
\text { all the proceeds are equally split among all the underwriters). }\end{array}$ \\
\hline Recapitalized $_{\text {it }}$ & $\begin{array}{l}\text { Dummy that takes the value } 1 \text { when and after a underwriter } i \text { receives public capital injection at year } t, 0 \\
\text { otherwise }\end{array}$ \\
\hline Reputable $_{\mathrm{i}}$ & $\begin{array}{l}\text { Dummy that takes the value } 1 \text { if the underwriter if the underwriter bank is ranked in the top five in the annual } \\
\text { league tables considering the market shares of the pre-bailout period, 2006-Sept. } 2008 \text {. }\end{array}$ \\
\hline \multicolumn{2}{|r|}{ Continuous reputation measures } \\
\hline UW-proceeds & $\begin{array}{l}\text { Reputation measure computed as each underwriter's total proceeds raised in the corporate bond markets during } \\
\text { the pre-bailout. }\end{array}$ \\
\hline UW-inv.ranking & $\begin{array}{l}\text { Reputation measure computed as the multiplicative inverse of the pre-bailout ranking position hold by an } \\
\text { underwriter. Inv.ranking }=\frac{1}{\text { Ranking position }}\end{array}$ \\
\hline UW-MW & $\begin{array}{l}\text { Reputation measure computed as } \\
\qquad \text { Pre }-M W_{j, \text { pre-bailout }}=\frac{\ln \left(\text { proceeds }_{j, \text { pre-bailout }}\right)}{\max _{i \in \mathrm{I}}\left(\ln \left(\text { proceed }_{i, \text { pre-bailout }}\right)\right.} * 100\end{array}$ \\
\hline \multicolumn{2}{|r|}{ Alternative reputation measures } \\
\hline Reputable $_{\mathrm{i}}$ HQ-firms & $\begin{array}{l}\text { Dummy that takes the value } 1 \text { if the underwriter bank is ranked in the top five considering only those bonds } \\
\text { issued by firms with a high grade or prime rating (above A+/A1) at launch during the pre-bailout period }\end{array}$ \\
\hline Reputable $_{\mathrm{i}}$ FI Star Analysts & $\begin{array}{l}\text { Dummy that takes the value } 1 \text { if the underwriter bank is ranked in the top five awarded banks based on the All- } \\
\text { Europe Fixed-Income Research Team awards (reported by Institutional Investor) during the pre-bailout period }\end{array}$ \\
\hline \multicolumn{2}{|r|}{ Instruments } \\
\hline Pol_Reg connection & $\begin{array}{l}\text { Dummy variable that equals one if the bank's chief executive (CEO) or president has previously served as a } \\
\text { politician, has been publicly appointed on a discretionary basis by the government or any public agency (i.e. } \\
\text { Secretary of State, Director General) or has served in a financial regulatory/supervisory agency or central bank. }\end{array}$ \\
\hline Prompt corrective power index & $\begin{array}{l}\text { Index that ranges from } 0 \text { to } 6 \text { according to the regulation levels of bank solvency deterioration that force } \\
\text { automatic actions, such as interventions. Built following Barth et al. (2013) from the Bank Regulation and } \\
\text { Supervision Survey. }\end{array}$ \\
\hline Bank opacity & Ratio of available for sale (AFS) securities to total securities \\
\hline \multicolumn{2}{|r|}{ Classical DID variables } \\
\hline Recapitalized $_{\mathrm{i}}$ & Dummy that takes the value 1 if the underwriter bank has been being recipient of a state capital injection. \\
\hline Post-Bailout Period $_{t}$ & $\begin{array}{l}\text { Dummy that takes the value } 1 \text { in 2009:Q1-2013:Q4 (following Berger et al., 2018, 2019; Berger \& Roman, } \\
\text { 2015, 2017; Duchin \& Sosyura, 2014) }\end{array}$ \\
\hline \multicolumn{2}{|r|}{ Alternative market share measure } \\
\hline Mkt.share proc. full & $\begin{array}{l}\text { Market share computed on annual proceeds raised in the corporate bond markets (in case of more underwriters } \\
\text { all the proceeds are given each of them). }\end{array}$ \\
\hline \multicolumn{2}{|r|}{ Intensity of recapitalization measures } \\
\hline Recapitalization Intensity & Continuous variable computed as total funds received by the underwriter to total assets \\
\hline Recapitalization Amount & Natural logarithm of the total funds received by the underwriter plus one: Ln (1+ Recapitalization amount) \\
\hline \multicolumn{2}{|r|}{ Reputational cutoff variables } \\
\hline Reputable Top 10, 15 or 20 & $\begin{array}{l}\text { Dummy that takes the value } 1 \text { if the underwriter bank is ranked in the top ten, fifteen or twenty respectively in } \\
\text { the annual league tables based on the pre-bailout market shares. }\end{array}$ \\
\hline $\begin{array}{l}\text { Reputable Top } 5-10,10-15 \text { or } \\
\text { 15- } 20\end{array}$ & $\begin{array}{l}\text { Dummy that takes the value } 1 \text { if the underwriter if the underwriter bank is ranked in the top } 5-10,10-15 \text { or } 15- \\
20 \text {, respectively in the annual league tables based on the pre-bailout market shares }\end{array}$ \\
\hline
\end{tabular}

Panel B. Determinants of underwriters' market shares

\begin{tabular}{|c|c|c|}
\hline Abnormal bond spreads & $\begin{array}{l}\text { Weighted bond spreads in a three -year window. } \\
\begin{aligned} & \text { Spread }(\text { in bps })= \alpha+\beta_{1} \text { Proceeds }+\beta_{2} \ln (\text { Proceeds })+\beta_{3} \ln (\text { Maturity }) \\
&+\beta_{4} \text { Callable Bond }+\beta_{5} \text { High }- \text { Yield Bond } \\
&+\beta_{6} \text { Domestic Bond }+\beta_{7} \text { Neg.Pledge Issuer } \\
&+ \text { Industries Dummies }+ \text { Countries Dummies }+e_{i} \\
& \text { Abnormal bond spread }=\text { Spread }- \text { Spread }\end{aligned} \\
\text { Abnormal fees are the weighted underwriting fees charged in a three -year window. }\end{array}$ & Dealogic \\
\hline Abnormal fees & $\begin{array}{l}\text { Weighted underwriting fees charged in a three }- \text { year window. } \\
\text { Fees (in \% of gross proceeds) } \\
\qquad \begin{aligned}=\alpha+\beta_{1} \text { Proceeds }+\beta_{2} \ln (\text { Proceeds })+\beta_{3} \ln (\text { Maturity }) \\
+\beta_{4} \text { Callable Bond }+\beta_{5} \text { High }- \text { Yield Bond }+\beta_{6} \text { Domestic } \\
+\beta_{7} \text { Neg.Pledge Issuer }+ \text { Industries Dummies } \\
+ \text { Countries Dummies }+e_{i} \\
\quad \text { Abnormal fees }=\text { fees }-\widehat{\text { fees }}\end{aligned}\end{array}$ & Dealogic \\
\hline Industry Specialization & $\begin{array}{l}\text { Herfindhal index calculated for each underwriter as } \sum_{j=1}^{n}\left(\frac{g_{i j}}{G_{i}}\right)^{2} \text { ( } \mathrm{g}_{\mathrm{ij}} \text { is the gross proceeds } \\
\text { issued by the underwriter " } \mathrm{i} \text { " in the two-digit SIC-industry " } \mathrm{j} \text { " and } \mathrm{G}_{\mathrm{i}} \text { is the total gross } \\
\text { proceeds issued by the underwriter " } \mathrm{i} \text { "). }\end{array}$ & Dealogic \\
\hline
\end{tabular}




\begin{tabular}{|l|l|c|}
\hline Number Star Analyst & $\begin{array}{l}\text { Number of analysts reported by Institutional Investor for each underwriter in the All-Fixed } \\
\text { Income Research Rankings. }\end{array}$ & Dealogic \\
\hline UW Lender & $\begin{array}{l}\text { Dummy that takes the value } 1 \text { if the underwriter bank has taken also the role of lead manager } \\
\text { in a loan issued by a firm in the same natural year. }\end{array}$ & Thomson ONE \\
\hline Lending market share & $\begin{array}{l}\text { Computed on annual proceeds lent for each sample underwriter as lead manager in the } \\
\text { European syndicate loan market (in case of more than one lender banks all the proceeds are } \\
\text { equally split among all the lenders) }\end{array}$ & Thomson ONE \\
\hline Weighted Private Placement & $\begin{array}{l}\text { Average ratio of Proceeds placed on private placement deals over total proceeds placed in } \\
\text { a three - year window }(t, t-1, t-2)\end{array}$ & Dealogic \\
\hline Weighted Multiple UW Deals & $\begin{array}{l}\text { Average ratio of Proceeds placed on multiple underwritten deals over total proceeds placed } \\
\text { in a three -year window }(t, t-1, t-2)\end{array}$ & Dealogic \\
\hline UW size & $\begin{array}{l}\text { Natural Logarithm of the total assets of the underwriter computed at the beginning of "t" } \\
\text { period }\end{array}$ & Bankscope \\
\hline Profitability (ROE) & Ratio of Net Income to Total Equity computed at the beginning of "t" period & Bankscope \\
\hline Liquidity & $\begin{array}{l}\text { Ratio of liquid Assets to Total Customer Deposits and Short Term Debt computed at the } \\
\text { beginning of "t" period }\end{array}$ & Bankscope \\
\hline Capital Adequacy & Ratio of capital Funds to total assets at the beginning of "t" period & Bankscope \\
\hline Operation Efficiency & Cost to income ratio computed at the beginning of " $t$ " period & Bankscope \\
\hline Age & $\begin{array}{l}\text { Natural Logarithm of the years since the first issuance of the Underwriter or previous } \\
\text { Underwriter since 1988 }\end{array}$ & Dealogic \\
\hline Listed & Dummy that takes the value 1 if the underwriter bank is listed in a stock exchange market. & Bankscope \\
\hline
\end{tabular}

Panel C. Determinants of underwriters' financial health

\begin{tabular}{|l|l|c|}
\hline UW size & $\begin{array}{l}\text { Natural Logarithm of the total assets of the underwriter computed at the beginning of " } \mathrm{t} \text { " } \\
\text { period }\end{array}$ & Bankscope \\
\hline Profitability (ROE) & Ratio of Net Income to Total Equity computed at the beginning of "t" period & Bankscope \\
\hline Liquidity & $\begin{array}{l}\text { Ratio of liquid Assets to Total Customer Deposits and Short Term Debt computed at the } \\
\text { beginning of "t" period }\end{array}$ & Bankscope \\
\hline Capital Adequacy & Ratio of capital Funds to total assets at the beginning of " $t$ " period & Bankscope \\
\hline Operation Efficiency & Cost to income ratio computed at the beginning of " $t$ " period & Bankscope \\
\hline Age & $\begin{array}{l}\text { Natural Logarithm of the years since the first issuance of the Underwriter or previous } \\
\text { Underwriter since 1988 }\end{array}$ & Dealogic \\
\hline Listed & Dummy that takes the value 1 if the underwriter bank is listed in a stock exchange market. & Bankscope \\
\hline
\end{tabular}

Panel D. Firm-bank matching

\begin{tabular}{|c|c|c|}
\hline Bond size & Natural logarithm of the bond proceeds & Dealogic \\
\hline Maturity & Natural logarithm of bond's time to maturity in years & Dealogic \\
\hline Callability & Dummy taking the value 1 if the bond includes a call option & Dealogic \\
\hline Domestic placement & Dummy taking the value 1 if the bond is placed domestically & Dealogic \\
\hline Investment Grade & Dummy taking the value 1 if the bond is an investment grade bond & Dealogic \\
\hline Syndicate size & Number of underwriters taking this role in the deal & Compustat \\
\hline Firm size & Natural logarithm of the issuer's total assets at the end of the year before the bond issue & Compustat \\
\hline Firm Leverage & Ratio of total liabilities to equity at the end of the year before the bond issue & Compustat \\
\hline Firm ROA & $\begin{array}{l}\text { Return on assets based on the net incomes and total assets at the end of the year before the } \\
\text { bond issue. }\end{array}$ & Compustat \\
\hline First-time issuer & $\begin{array}{l}\text { Dummy taking the value } 1 \text { if the bond is the first bond issued by the issuer in the last } 15 \\
\text { years }\end{array}$ & Dealogic \\
\hline $\begin{array}{l}\text { Firm - Bank Shared } \\
\text { nationality }\end{array}$ & Dummy taking the value 1 if firm and bank are located in the same country & Dealogic \\
\hline \multirow{2}{*}{ Prior Firm-UW Relationships } & Amount of bonds proceeds by bank $i$ to firm $j 2$ years before the bond issue & \multirow{2}{*}{ Dealogic } \\
\hline & Total bonds proceeds by bank $i$ to firm $j 2$ years before the bond issue & \\
\hline \multirow{2}{*}{$\begin{array}{l}\text { Prior Firm-Lending } \\
\text { Relationships }\end{array}$} & Amount of loans by bank $i$ to firm $j 2$ years before the bond issue & \multirow{2}{*}{ Thomson ONE } \\
\hline & Total bonds proceeds by bank $i$ to firm $j 2$ years before the bond issue & \\
\hline
\end{tabular}

Panel E. Other determinants of being bailed-out

\begin{tabular}{|l|l|c|}
\hline Interbank Lendings & Loans and advances to banks to total assets at the beginning of period " $t$ " & Bankscope \\
\hline Regulatory Quality & $\begin{array}{l}\text { Ability of the government to formulate and implement sound policies and regulations that } \\
\text { permit and promote private sector development }\end{array}$ & World Bank \\
\hline Stock Markets Volatility & $\begin{array}{l}\text { Standard deviation of the index price of the main stock market of the country in which the } \\
\text { bank is domiciled }\end{array}$ & $\begin{array}{c}\text { OECD } \\
\text { database }\end{array}$ \\
\hline GDP Growth & Growth in the GDP of the country where the bank is domiciled & World Bank \\
\hline Economic Freedom & $\begin{array}{l}\text { Composite Index that accounts for the rule of law, government size, regulatory efficiency } \\
\text { and open markets in order to offer a measure of how in economically free societies, } \\
\text { governments allow labor, capital, and goods to move freely, and refrain from coercion or } \\
\text { constraint of liberty beyond the extent necessary to protect and maintain liberty itself. }\end{array}$ & $\begin{array}{c}\text { Heritage } \\
\text { Foundation }\end{array}$ \\
\hline
\end{tabular}




\section{APPENDIX B}

TABLE B

RECAPITALIZATION MEASURES RECEIVED BY UNDERWRITERS (2006 - 2013)

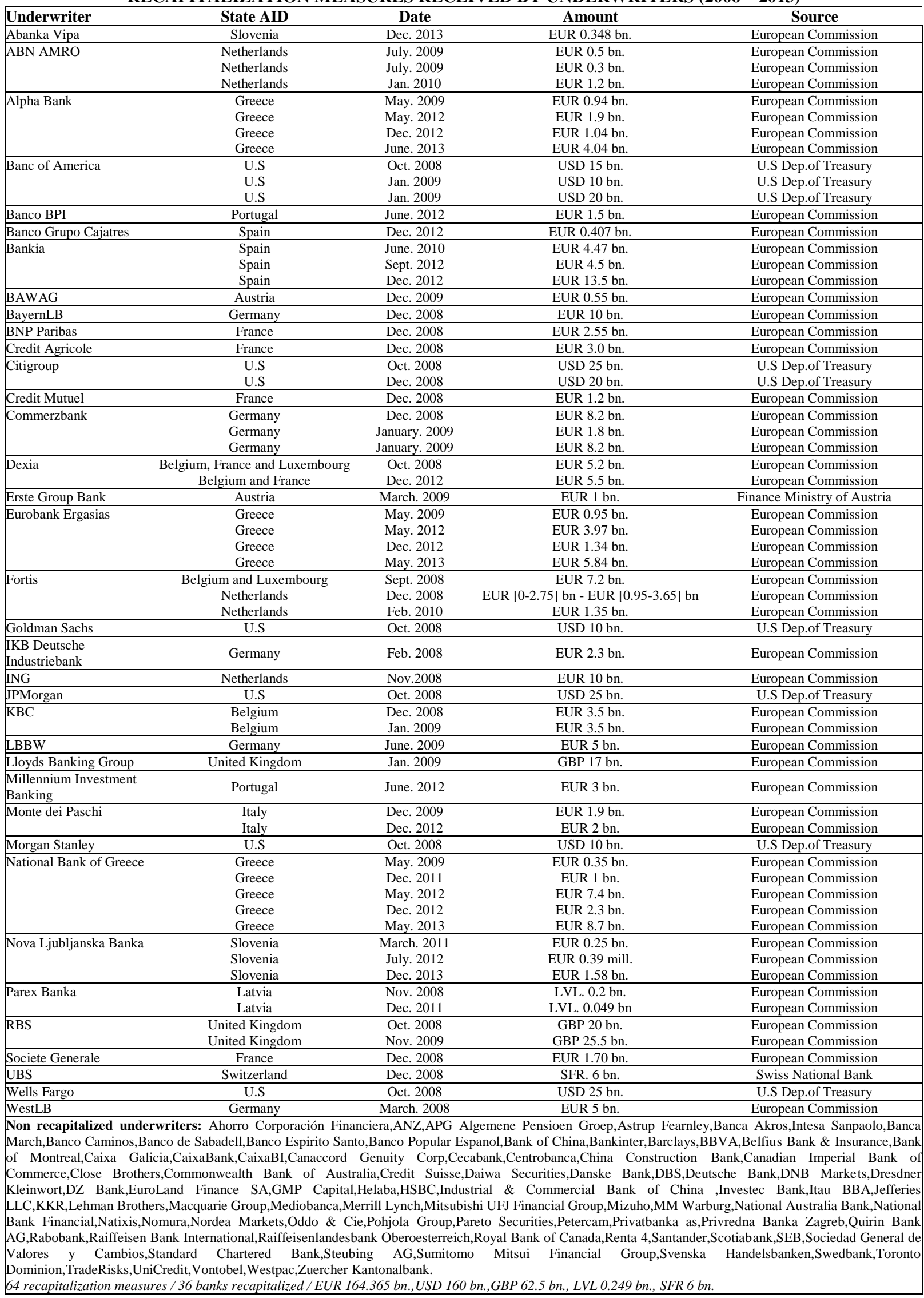

